\title{
Altered Expression of Bone Morphogenetic Protein Accessory Proteins in Murine and Human Pulmonary Fibrosis
}

Noelle Murphy, ${ }^{* \dagger}$ Katherine U. Gaynor, ${ }^{*}$ Simon C. Rowan, ${ }^{*}$ Sinead M. Walsh, ${ }^{* \dagger}$ Aurelie Fabre, ${ }^{\S}$ John Boylan, ${ }^{\dagger}$ Michael P. Keane, ${ }^{* \ddagger}$ and Paul McLoughlin ${ }^{* \star}$

From the School of Medicine, * Conway Institute, University College Dublin, Dublin; and the Departments of Anaesthesia and Intensive Care Medicine ${ }^{\dagger}$ and Histopathology ${ }^{\S}$ and the School of Medicine, ${ }^{\ddagger}$ St Vincent’s University Hospital, Dublin, Ireland

Accepted for publication October 30, 2015.

Address correspondence to Paul McLoughlin, M.B., B.Ch., Ph.D., UCD School of Medicine, Health Sciences Centre, University College Dublin, Belfield, Dublin 4, Ireland. E-mail: paul. mcloughlin@ucd.ie.

\begin{abstract}
Idiopathic pulmonary fibrosis is a chronic, progressive fibrotic disease with a poor prognosis. The balance between transforming growth factor $\beta 1$ and bone morphogenetic protein (BMP) signaling plays an important role in tissue homeostasis, and alterations can result in pulmonary fibrosis. We hypothesized that multiple BMP accessory proteins may be responsible for maintaining this balance in the lung. Using the bleomycin mouse model for fibrosis, we examined an array of BMP accessory proteins for changes in mRNA expression. We report significant increases in $m$ RNA expression of gremlin 1, noggin, follistatin, and follistatin-like 1 (Fstl1), and significant decreases in mRNA expression of chordin, kielin/chordin-like protein, nephroblastoma overexpressed gene, and BMP and activin membrane-bound inhibitor (BAMBI). Protein expression studies demonstrated increased levels of noggin, BAMBI, and FSTL1 in the lungs of bleomycin-treated mice and in the lungs of idiopathic pulmonary fibrosis patients. Furthermore, we demonstrated that transforming growth factor $\beta$ stimulation resulted in increased expression of noggin, BAMBI, and FSTL1 in human small airway epithelial cells. These results provide the first evidence that multiple BMP accessory proteins are altered in fibrosis and may play a role in promoting fibrotic injury. (Am J Pathol 2016, 186: 600-615; http://dx.doi.org/10.1016/j.ajpath.2015.10.032)
\end{abstract}

Idiopathic pulmonary fibrosis (IPF) is a chronic, progressive fibrotic disease of unknown cause that is limited to the lungs. Prognosis is extremely poor, with a median survival of 3 to 5 years after diagnosis. Transforming growth factor (TGF)- $\beta 1$ has been shown to be a key mediator of fibrosis in the lung. Bone morphogenetic proteins (BMPs) are multifunctional growth factors belonging to the TGF- $\beta$ superfamily, and it has been postulated that increased TGF- $\beta 1$ signaling with a concomitant reduction in BMPs is an important driver of inflammation and fibrosis. ${ }^{1}$ Moreover, there is growing evidence that the interactions between members of the TGF- $\beta$ superfamily and the accessory proteins that modulate TGF- $\beta$ superfamily signaling are important in the development of an array of inflammatory and fibrotic diseases in the lung. ${ }^{2}$ It is clear that members of the TGF- $\beta$ superfamily are important regulators of pulmonary homeostasis, and alterations in TGF$\beta$ superfamily signaling contribute to the development of pulmonary pathology. In particular, reductions in BMP signaling are pivotal in the development of pulmonary hypertension, pulmonary fibrosis, and pulmonary inflammation. 1,3,4 Furthermore, attenuated BMP signaling is a recognized feature of inflammatory and fibrotic conditions in other organ systems, including the joints, kidneys, and liver. $^{5-7}$

In many disorders, reduced BMP signaling is associated with a concomitant rise in TGF- $\beta 1 /$ activin signaling. Thus, balanced BMP and TGF- $\beta 1 /$ activin signaling may be a

Supported by Health Research Board-Science Foundation Ireland grant TRA/2011/33, Health Research Board grant POR/2012/65, Science Foundation Ireland grant SFI 12/IA/1477, St. Vincent's Anesthesia Foundation, and the Abbot Scholarship for Anesthetic Research, College of Anaesthetists Ireland (N.M.).

N.M. and K.U.G. contributed equally to this work.

Disclosures: None declared. 
crucial determinant of regeneration or repair after injury versus maladaptive healing by fibrosis. It has already been shown that one BMP accessory protein, gremlin1 (a BMP antagonist), is up-regulated in IPF. ${ }^{1}$ Gremlin1 is one of a larger group of BMP accessory proteins, some of which also bind to TGF- $\beta 1$ or activin. ${ }^{8,9}$ We hypothesized that during the disease process, the altered expression of a number of different BMP accessory proteins may lead to an imbalance in TGF- $\beta 1 / B M P$ signaling, resulting in fibrosis. To test this hypothesis, we utilized a well-established mouse model of fibrosis in which intratracheal administration of bleomycin provides an initial inflammatory response that heals by fibrosis, resembling the changes seen in human lung injury. ${ }^{10}$ We examined the expression levels of a number of BMP accessory proteins that are known to play a role in lung diseases, are implicated in lung organogenesis, or are known to be expressed in the lung. We selected key targets to investigate further, looking at levels of protein expression in fibrotic mouse and human tissue and at the effects of TGF- $\beta 1$ induction on expression of these inhibitors in human small airway epithelial cells (SAECs).

\section{Materials and Methods}

\section{Animals}

All procedures involving animals were approved by the University College Dublin Animal Research Ethics Committee and licensed by the Department of Health and Children in accordance with European Communities Regulations 2002 (Amendment of Cruelty to Animals Act 1876) and EU Directive 2010/63/EU. Specific pathogen-free adult male C57Bl/6J wild-type mice ( 25 to $32 \mathrm{~g}$ at 10 to 15 weeks old) were used in all experiments. Specific pathogen-free status was as defined in the Federation of Laboratory Animal Science Association guidelines. ${ }^{11}$ All animals were exposed to the same 12:12-hour light-dark cycle, and food and water were provided ad libitum. Animals were housed singly in individually ventilated cages for the duration of the study, maintaining specific pathogen-free status. All mice used in the study were reared in the animal facility from birth, and specific pathogen-free status was according to the Federation of Laboratory Animal Science Association guidelines. ${ }^{11}$

\section{Bleomycin Mouse Model}

Mice were randomly allocated by grab sampling to either a saline (control) or bleomycin-inoculated group ( $n=12$ per group). Mice were anesthetized by i.p. injection of 100 $\mathrm{mg} / \mathrm{kg}$ ketamine (Vetalar; Pfizer, Sandwich, Kent, UK). Intratracheal instillation was used to deliver either $1 \mathrm{U} / \mathrm{kg}$ of bleomycin (Bleo-Kyowa; Kyowa Hakko Ltd, Slough, UK) in $50 \mu \mathrm{L}$ of normal saline or $50 \mu \mathrm{L}$ of normal saline alone, as described. ${ }^{12}$ In brief, once anesthetized, the mice were suspended on a custom-made Perspex intubation stand (made in-house) at an angle of 70 degrees by their front incisors. The tongue was carefully pulled out and an otoscope (Welch Allyn 3.5 V Diagnostic Otoscope; Welch Allyn Ltd, Meath, Ireland) with a pediatric tip was inserted into the mouth until the epiglottis came into view. A metal applicator was used to apply lidocaine jelly (Instillagel; Farco-Pharma, Berlin, Germany) posterior to the epiglottis. The otoscope was removed for 2 minutes, giving the lidocaine time to anesthetize the vocal cords, and then reinserted into the mouth, after which a 22-gauge catheter (Jelco, Dublin, Ireland) mounted with a guide wire was passed through the vocal cords. On confirmation of correct placement of the catheter, either bleomycin $(1 \mathrm{U} / \mathrm{kg}$ in $50 \mu \mathrm{L}$ of normal saline) or $50 \mu \mathrm{L}$ normal saline alone was instilled down the intratracheal catheter. A Stepper Repetitive Dispensing Pipette (Dymax, Kildington, Oxfordshire, UK) was used to ensure that the exact volume was administered to each mouse. The mice were extubated and allowed to recover from anesthesia in a warming chamber. One mouse from each group died during or immediately after the inoculation procedure; thus, lungs from 11 animals were available for analysis. Mice were housed individually after inoculation in individually ventilated cages and observed daily for adverse clinical signs, including the following: appearance (eg, signs of dehydration, piloerection, lack of grooming), body weight, behavior (eg, alterations in mobility, vocalization), respiratory rate, and signs of pain. If animals were deemed to be suffering more than moderate adverse effects or had lost more than $20 \%$ of their initial body weight, they were sacrificed by overdose of anesthesia before the predefined study time had elapsed.

Fourteen days after instillation, mice were sedated by brief inhalation of 2\% isoflurane (Vetflurance, Virbac, Suffolk, UK) in oxygen vapor and then given an i.p. injection of $60 \mathrm{mg} / \mathrm{kg}$ sodium pentobarbital (Rhône Merieux Ltd, Harlow, UK) and $1000 \mathrm{IU} / \mathrm{kg}$ anticoagulated with heparin (Leo Laboratories Ltd, Maidenhead, Berkshire, UK). They were then returned to their cage and breathed room air until confirmation of an adequate depth of anesthesia by absence of response to tail compression; the femoral artery was then incised and the mice sacrificed by exsanguination. Post mortem a ligature was passed around the right main bronchus to tie off the right lung. The right lung was removed, snap-frozen in liquid nitrogen, weighed, and then used for mRNA analysis. The remaining lung was fully inflated via a tracheal cannula with fixative [4\% (w/v) paraformaldehyde] at a pressure of $25 \mathrm{~cm} \mathrm{H}_{2} \mathrm{O}$ for $30 \mathrm{mi}$ nutes. After lung inflation, the left main bronchus was ligated at the level of the hilum. The left lung was left in fixative for 24 hours. The volumes of the left lungs were then measured by water displacement. ${ }^{13}$ Two lungs from the bleomycin-inoculated group were punctured at the time of isolation and thus could not be inflated; consequently, they were not available for further histological study. One additional lung was excluded from each group for technical reasons, leaving 10 and 8 lungs available for stereological analysis in the control and bleomycin groups, respectively. 
Table 1 Antibodies Used in the Study

\begin{tabular}{|c|c|c|c|c|}
\hline Primary $A b$ & Company & Code & Technique & Dilution \\
\hline $\mathrm{PO}_{4}$ Smad 2 & Cell Signaling Technologies & 3107 & WB (mouse) & $1: 500 *$ \\
\hline Total Smad2 & Cell Signaling Technologies & 3108 & WB (mouse) & $1: 1000^{\dagger}$ \\
\hline $\mathrm{PO}_{4}$ Smad 3 & Cell Signaling Technologies & 9520 & WB (mouse) & $1: 500$ * \\
\hline Total Smad 3 & Cell Signaling Technologies & 9513 & WB (mouse) & $1: 1000^{*}$ \\
\hline $\mathrm{PO}_{4}$ Smad $1 / 5 / 8$ & Cell Signaling Technologies & 95115 & WB (mouse) & $1: 2000^{\ddagger}$ \\
\hline Total Smad 1/5/8 & Cell Signaling Technologies & sc6031R & WB (mouse) & $1: 200^{\ddagger}$ \\
\hline & Abcam & Ab16054 & IHC (human) & 1.200 \\
\hline \multirow[t]{3}{*}{ BAMBI } & R\&D Systems & AF2387 & WB (mouse) & $1: 200$ * \\
\hline & & & IHC (mouse) & $1: 120^{\S}$ \\
\hline & R\&D Systems & AF921 & IHC (human) & 1.25 \\
\hline \multirow[t]{2}{*}{ Follistatin-like 1} & R\&D Systems & AF1738 & WB (mouse) & $1: 500^{\top}$ \\
\hline & & & IHC (mouse) & $1: 90^{\|}$ \\
\hline
\end{tabular}

*Secondary antibody raised against rabbit, dilution 1:2000.

'Secondary antibody raised against mouse, dilution 1:2000.

${ }^{\ddagger}$ Secondary antibody raised against rabbit, dilution 1:5000.

${ }^{\S}$ Secondary antibody raised against rabbit, dilution 1:150.

"Secondary antibody raised against goat, dilution 1:2000.

"Secondary antibody raised against goat, dilution 1:150.

**Secondary antibody raised against rabbit, dilution 1:10,000.

Lung injury was quantified with stereological techniques to determine the volume of the alveolar wall, including all of the inflammatory cell infiltrate and fibrotic extracellular matrix within the gas exchange regions of the lungs, as recommended by the joint American Thoracic Society/ European Respiratory Society policy statement on tissue quantification. ${ }^{14}$ After fixation, the vertical axis of the lung was identified and the lung was cut into 3-mm-thick slabs perpendicular to the vertical axis of the lung, with a random starting point chosen from within the first $3 \mathrm{~mm}$ of lung. This resulted in five to six slabs per left lung. These lung slabs were then embedded in paraffin wax, using the characteristic shape of each slab to maintain the vertical orientation. Sections ( $5 \mu \mathrm{m}$ thick) were cut from each slab until a series of complete transverse sections (ie, completely surrounded by pleural surface) had been obtained, and then one was stained with hematoxylin and eosin for histological assessment.

Multiple microscopic images of lung tissue were selected from within each section by using a systematic random selection strategy (Olympus BX61 motorized microscope with an $\times 20$ objective; Olympus, Albertslund, Denmark). These images were selected using the Computer-Assisted Stereological Tool system software (Visopharm Integrator System version 2.9.11.0, Olympus), which controls movement of the microscope stage so that the selection of the fields of view is independent of the observer. The number of fields of view taken from each section was proportional to the area of that section. The computer program superimposed a $6 \times 6$-point counting grid on each histological image. Because the position of the sections within the lung, the microscopic fields of view, and the position of the counting grid were randomly selected, the probability of a point being superimposed on lung tissue or airspace was directly proportional to the fraction of the total volume of the lung occupied by that feature. The observer who counted the number of points falling on tissue or airspace was not informed of the treatment received by that lung. Determination of the fraction of the lung occupied by lung tissue (including all cells, extracellular matrix, and inflammatory cells) and the volume of each lung (measurement by water displacement) permitted calculation of the total tissue volume in that lung.

Additional sections were stained with picrosirius red to identify collagen. Sections $(4 \mu \mathrm{m})$ were deparaffinized in xylene, rehydrated, and treated with in $0.2 \%(\mathrm{v} / \mathrm{v})$ aqueous phosphomolybdic acid. Sections were stained using a $0.1 \%$ (w/v) solution of Sirius Red (Sigma Aldrich, Dublin, Ireland) in saturated aqueous picric acid (Sigma Aldrich) for 90 minutes. Subsequently, sections were rinsed in $0.4 \%$ (v/v) $\mathrm{HCl}$ solution and were then dehydrated in ascending concentrations of ethanol, cleared with xylene, and coverslipped. Sections were viewed under polarized light, and 20 random images were acquired $(\times 10$ objective $)$ from each lung, digitized, and analyzed using ImageJ software version 1.48v (NIH, Bethesda, MD; http://imagej.nih.gov/ij). The signal in the green channel was segmented to allow measurement of the percentage of the area of each image that contained collagen, as identified by birefringence.

A second independent set of intratracheal inoculations of saline $(n=8)$ control or bleomycin $(n=8)$ was then completed, as previously described. Fourteen days after saline or bleomcyin instillation, the left and right lungs were 
Table 2 Applied Biosystems Gene Expression Assays

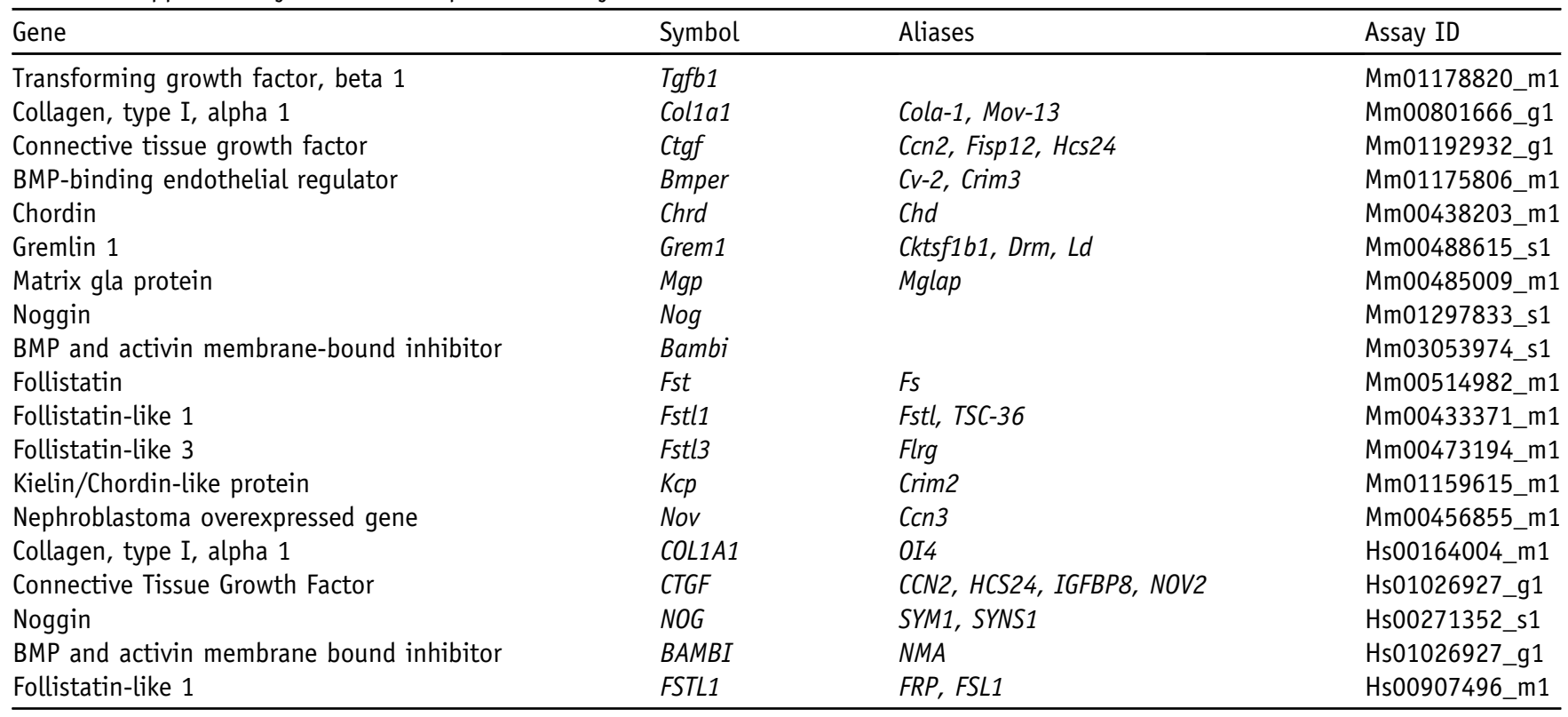

isolated post mortem and immediately snap-frozen. Protein was extracted from the left lungs for use in enzyme-linked immunosorbent assay and from corresponding right lungs for use in Western blot analysis.

\section{Enzyme-Linked Immunosorbent Assay}

Protein suitable for enzyme-linked immunosorbent assay was extracted from lung homogenized in phosphate-buffered saline with added protease inhibitors and used in commercially produced kits (R\&D Systems, Abingdon, Oxfordshire, UK) to quantify Bmp2, activin, and TGF- $\beta 1$ concentrations.

\section{Western Blot Analysis}

Flash-frozen whole lung lysates were prepared in radioimmunoprecipitation assay buffer (Merck Millipore, Billerica, MA), homogenized by mechanical disruption (Tissue Ruptor; Qiagen, Hilden, Germany), and sonicated to ensure adequate lysis. Equal amounts of protein extract were separated by SDS-PAGE, transferred onto polyvinylidene difluoride membranes, and detected with appropriate antibodies and secondary antibodies labeled with horseradish peroxidase (Table 1). After incubation with secondary antibody, proteins were visualized with an enhanced chemiluminescent signal kit (Pierce ECL Western Blotting Substrate; Thermo Fisher Scientific, Waltham, MA). An identical amount of protein from a single standard sample formed by pooling homogenate from lungs isolated from mice in the saline control group was loaded onto each gel to act as a loading and transfer control. Densitometric analysis was performed using ImageJ software in two stages: the density of the target band was normalized to the endogenous loading control (GAPDH) for that sample, and the resultant value was normalized to the corresponding value for the pooled standard sample on that gel.

\section{Analysis of Gene Expression}

Total mRNA was extracted from tissue and cell pellets were snap-frozen in liquid nitrogen using the Qiagen RNeasy Minikit (Qiagen) according to the manufacturer's protocol. Total RNA (1 $\mu \mathrm{g})$ was reverse transcribed to cDNA using a SuperScript II Reverse Transcriptase kit (Invitrogen, Carlsbad, CA). Real-time PCR was performed on 384-well plates, and each sample was measured in duplicate. An initial minus reverse transcriptase reaction confirmed that all RNA samples were free of contaminating genomic DNA. Probes were ordered as Assay-On-Demand Gene Expression Assays (Applied Biosystems, Foster City, CA) (Table 2). Reactions were performed on the Applied Biosystems PRISM 7900 Sequence Detection System (Applied Biosystems), and mRNA levels were determined using the comparative threshold method. ${ }^{15}$ We selected BMP accessory proteins previously reported to play a role in lung diseases, including gremlin 1, follistatin, noggin, BMPbinding endothelial regulator (BMPER), and BMP and activin membrane-bound inhibitor (BAMBI) ${ }^{1,16-18}$; BMP accessory proteins implicated in lung organogenesis, including follistatin-like 1 (FSTL1), matrix GLA protein (MGP), and chordin in the bleomycin model of lung injury ${ }^{19-21}$; and BMP accessory proteins known to be expressed in the normal lung: follistatin-like 3 (FSTL3), nephroblastoma overexpressed gene $(\mathrm{NOV})$, and kielin/chordin-like protein $(\mathrm{KCP}){ }^{22,23}$

\section{Immunostaining}

Immunohistochemical localization of BAMBI, FSTL1, and noggin was performed on paraffin-embedded lung sections 
A

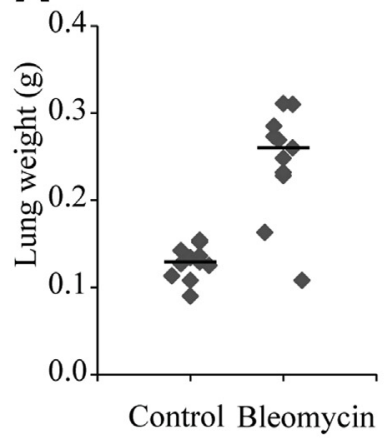

C

\section{Saline}
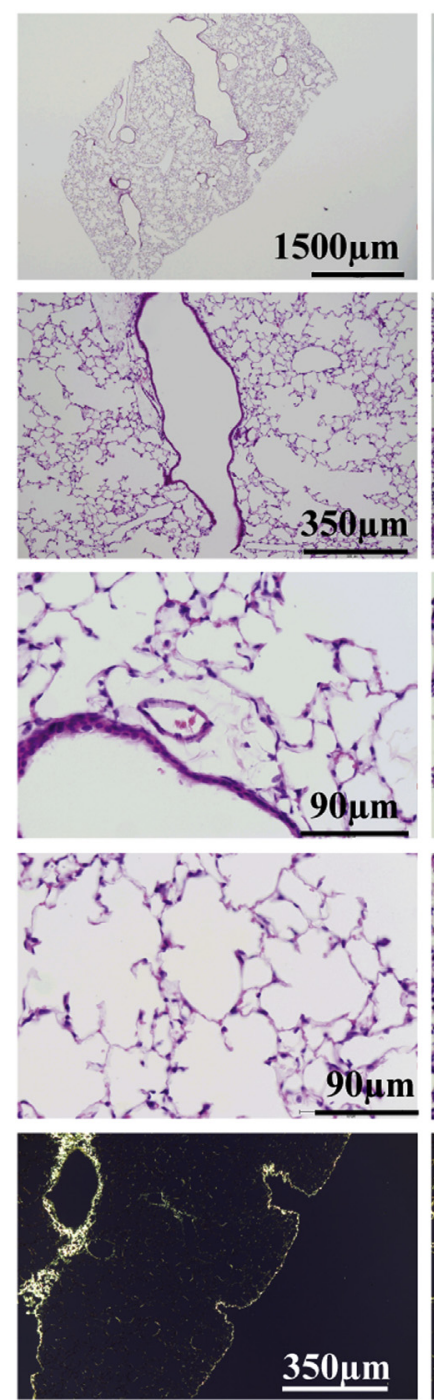

D
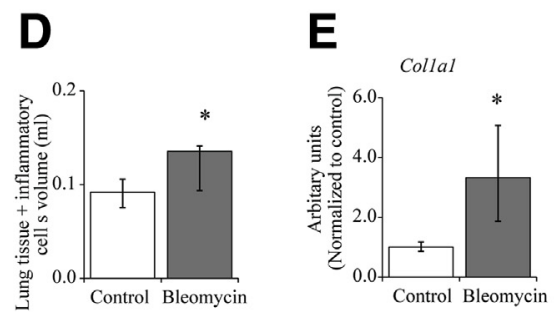

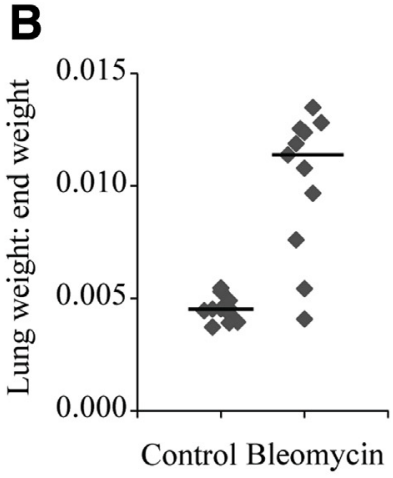

Bleomycin
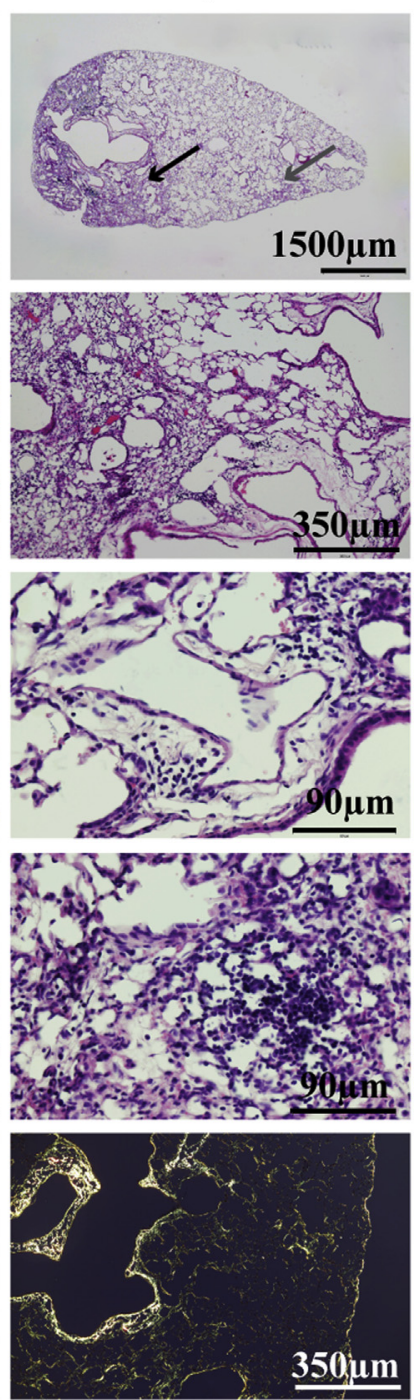

$\mathbf{F}$

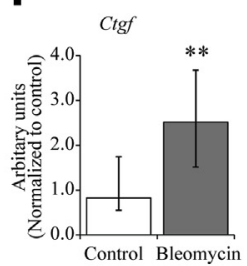

from wild-type mice sacrificed 14 days after instillation of bleomycin or saline, as previously described. ${ }^{24}$ Briefly, $5-\mu \mathrm{m}$-thick sections were cut from the surface of each slice and mounted onto poly-1-lysine-coated glass slides (Sigma, St. Louis, MO). Slides were baked for 18 hours at $37^{\circ} \mathrm{C}$, dewaxed, and hydrated. Endogenous peroxidase activity was blocked by exposure to hydrogen peroxide $(0.3 \% \mathrm{v} / \mathrm{v})$ in ethanol $(70 \%)$. Antigen retrieval was undertaken for 20 minutes in $10 \mathrm{mmol} / \mathrm{L}$ sodium citrate buffer $(\mathrm{pH} 6.0)$ at a controlled temperature $\left(95^{\circ} \mathrm{C}\right)$ in a water bath. Slides were washed in phosphate-buffered saline and blocked in appropriate serum (10\% diluted in phosphate-buffered saline) for 1 hour. Tissue sections were incubated in primary antibody (Table 1), diluted in phosphate-buffered saline, and left for 18 hours at $4^{\circ} \mathrm{C}$ in humidified Petri dishes. Appropriate biotin-labeled secondary antibodies were used to detect specific binding using streptavidin-linked horseradish peroxidase and diaminobenzidine (Sigma Aldrich). The slides were then counterstained with hematoxylin (Lennox Laboratory Supplies, Dublin, Ireland) before being examined microscopically on an Olympus BX61 microscope $(\times 40$ objective).

\section{Human Lung Tissue}

Human IPF tissue was collected from explanted lungs at the time of lung transplantation $[n=6$, all male, mean age 59.6 years (range 41 to 68 years)]. Control lung tissue was obtained by taking tissue blocks from lobectomy samples removed for surgical excision of cancer at a site remote from the tumor ( $n=3$, anonymized data). The protocols were approved by the hospital ethics committee (Mater Misericordiae University Hospital, Dublin, Ireland), and all patients gave written informed consent. IPF was diagnosed according to the 2011 official American Thoracic Society/European Respiratory Society/Japanese Respiratory Society/Latin American Thoracic Association statement "Idiopathic Pulmonary Fibrosis:

\footnotetext{
Figure 1 Treatment with intratracheal bleomycin results in lung damage and fibrosis. A: Absolute right lung weights 14 days after intratracheal administration of bleomycin. B: Right lung weights relative to final body weight 14 days after intratracheal administration of bleomycin. C: Representative images of hematoxylin and eosin-stained lungs 14 days after intratracheal administration of bleomycin showing bronchocentric injury (black arrow), small patches adjacent to the plural surface (gray arrow), perivascular and peribronchial inflammatory cells, and significant alveolar injury with loss of airspace, thickening of alveolar walls, and intra-alveolar inflammatory cells in bleomycin-treated mice compared with in normal saline controls. Bottom two panels show polarized light images of picrosirius red staining. D: Stereological analysis of volume of lung tissue plus inflammatory cells 14 days after intratracheal administration of bleomycin. $\mathbf{E}$ and $\mathbf{F}$ : mRNA expression of the TGF- $\beta$-inducible genes Col1a1 and Ctgf after bleomycin instillation. Data are expressed as medians ( $\mathbf{A}$ and $\mathbf{B}$ ) and medians \pm interquartile range (D-F). mRNA values (E and $\mathbf{F})$ are expressed as fold change relative to mean salineinoculated control value. ${ }^{*} P<0.05$ and ${ }^{* *} P<0.01, U$-test. $n=11$ per group (A, B, E, and F); $n=10$ and 8 for control and bleomycin groups, respectively (D). TGF- $\beta$, transforming growth factor $\beta$.
} 
Table 3 mRNA Expression of a Panel of BMP-Related Proteins in Wild-Type Mouse Lung Lysates, 14 Days after Intratracheal Instillation of Bleomycin

\begin{tabular}{|c|c|c|c|}
\hline \multirow[b]{2}{*}{ TGF- $\beta$ superfamily ligand group } & \multirow[b]{2}{*}{ Accessory protein } & \multicolumn{2}{|c|}{ Relative mRNA expression } \\
\hline & & Control & Bleomycin treated \\
\hline \multirow[t]{4}{*}{ BMP only } & BMPER $^{29,30}$ & $1.1(0.6-1.4)$ & $1.1(0.7-1.3)$ \\
\hline & Gremlin $1^{32}$ & $1.1(0.9-1.2)$ & $12.6(4.0-15.0)^{* *}$ \\
\hline & MGP $^{33,34}$ & $1.0(0.9-1.2)$ & $1.3(1.1-1.5)$ \\
\hline & Noggin $^{35}$ & $0.9(0.8-1.4)$ & $1.5(1.3-2.5)^{*}$ \\
\hline \multirow{4}{*}{ BMP and TGF- $\beta$ /activin } & Follistatin-like $1^{22,38,39}$ & $1.0(0.9-1.3)$ & $1.7(1.3-2.0)^{* *}$ \\
\hline & Follistatin-like $3^{22,40}$ & $1.0(0.9-1.1)$ & $0.9(0.7-1.4)$ \\
\hline & $\mathrm{KCP}^{41-43}$ & $1.0(0.8-1.5)$ & $0.5(0.3-0.6)^{* *}$ \\
\hline & $\mathrm{NOV}^{44}$ & $0.9(0.8-1.2)$ & $0.3(0.2-0.4) * *$ \\
\hline
\end{tabular}

Data are expressed as medians \pm interquartile range. Values are displayed as fold change relative to mean saline-inoculated control value. $n=11$ per group, except for NOV, where $n=10$ for technical reasons.

${ }^{\star} P<0.05,{ }^{* *} P<0.01, U$-test.

Evidence-Based Guidelines for Diagnosis and Management." ${ }^{25}$ Human tissue slides were stained on the Automated Dako Autostainer Link 48 (DakoCytomation Ireland Ltd, Galway, Ireland) by using Dako antigen retrieval buffer at $\mathrm{pH} 6.0$ and EnVision Flex and LSAB+ kits (DakoCytomation Ireland Ltd).

\section{Cell Culture Experiments}

Cell culture experiments were performed with primary human SAECs (Lonza, Basel, Switzerland) obtained from a 19-yearold male nonsmoker. The SAECs were maintained in SAEC growth medium (Lonza) at $37^{\circ} \mathrm{C}$ in $5 \% \mathrm{CO}_{2}$. All cells used in these experiments were between passages 5 and 7 and were routinely checked to confirm absence of Mycoplasma contamination by the MycoAlert assay (Cambrex Bioscience, Nottingham, UK). SAECs were seeded onto 12-well plates and grown until $80 \%$ confluency. The medium was changed, and the cells were either treated with $10 \mathrm{ng} / \mathrm{mL}$ TGF- $\beta 1$ (R\&D Systems) in $4 \mathrm{mmol} / \mathrm{L} \mathrm{HCl}$ containing $1 \%$ bovine serum albumin or treated with vehicle alone (sterile $4 \mathrm{mmol} / \mathrm{L} \mathrm{HCl}$ containing $1 \%$ bovine serum albumin), as a control. After 72 hours of treatment, the cells were lysed and RNA extracted for further analysis, as described above in Analysis of Gene Expression. These conditions were chosen because they had previously been shown to lead to the expression of markers of epithelial-mesenchymal transition in these cells by RT-qPCR (cadherin 1, vimentin, and $\alpha$-smooth muscle actin) and Western blot analysis with densitometry (cadherin 1, zona occludens 1 , vimentin, and $\alpha$-smooth muscle actin). ${ }^{26}$

\section{Statistical Analysis}

Normally distributed data are reported as means \pm SEM, whereas non-normally distributed data are presented as medians \pm interquartile range. For normally distributed data, statistical significance of differences between two group means was determined with $t$-tests. For non-normally distributed data, statistical significance was determined by using the $U$-Test (unpaired test); $P$ values were computed using the exact permutation method. $P<0.05$ was accepted as statistically significant.

\section{Results}

Treatment with Intratracheal Bleomycin Results in Lung Fibrosis

At the start of the study there was no significant difference in body weight between groups: median weight was $29.0 \mathrm{~g}$ (27.5 to $30.5 \mathrm{~g})$ in the control group $(n=11)$ and $29.0 \mathrm{~g}$ $(27.8$ to $30.3 \mathrm{~g})$ in the bleomycin-treated group $(n=11)$. Intratracheal bleomycin treatment led to significant weight loss $(-3.75 \mathrm{~g} \pm 0.63 \mathrm{~g})$ compared with saline-inoculated mice $(-0.45 \mathrm{~g} \pm 0.36 \mathrm{~g} ; P<0.01)$. Two of the bleomycin-treated animals had to be sacrificed humanely before the 14-day period after instillation had elapsed because of excessive ( $>20 \%$ ) weight loss (on day 7 and day 11).

In the second group of mice used to investigate protein levels of BMP accessory proteins, all mice survived the course of the study, although the bleomycin-treated mice still had significant weight loss $(-3.80 \mathrm{~g} \pm 0.73 \mathrm{~g})$ compared with the saline-inoculated mice $(-0.25 \mathrm{~g} \pm 0.18 \mathrm{~g} ; P<0.001)$. Median lung weight was significantly increased in animals treated with bleomycin compared with in those treated with saline, both when expressed as absolute lung weight and when lung weight was corrected for the final body weight (Figure 1, A and B). This was replicated in the later 14-day study.

Histological examination of the lungs (Figure 1C) demonstrated bronchocentric injury, small patches adjacent to the plural surface, perivascular and peribronchial 


\section{A TGF- $\beta$}

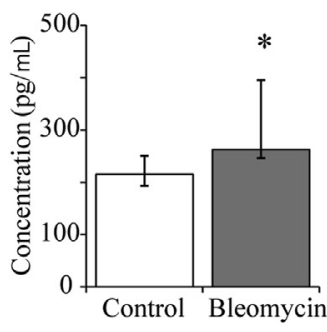

B

PSMAD 2

$60 \mathrm{kDa}$

TSMAD 2

$60 \mathrm{kDa}$

GAPDH

$37 \mathrm{kDa}$

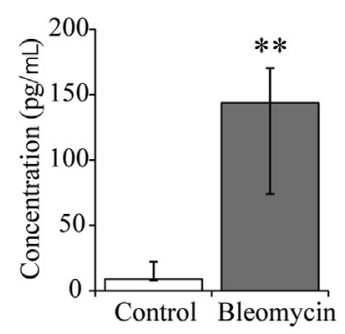

\section{$\begin{array}{lllllllll}C & B & C & B & C & B & C & B & \text { PS }\end{array}$}

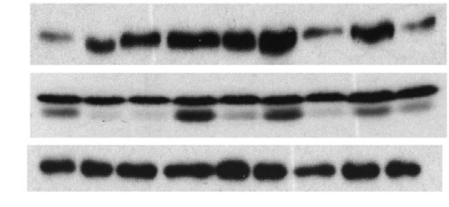

C

PSMAD $1 / 5 / 8$

$60 \mathrm{kDa}$

TSMAD 1/5/8

$60 \mathrm{kDa}$

GAPDH

$37 \mathrm{kDa}$

\section{$\begin{array}{lllllllll}\text { C } & \text { B } & \text { C } & \text { B } & \text { C } & \text { B } & \text { C } & \text { B } & \text { PS }\end{array}$}

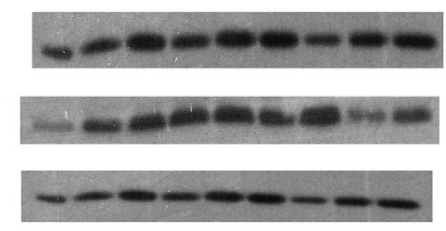

BMP2

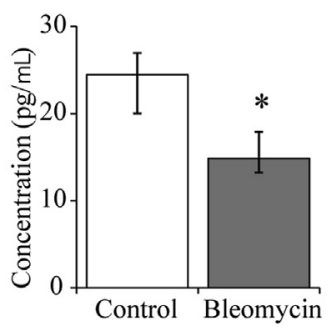

Figure 2 Treatment with intratracheal bleomycin results in changes in TGF- $\beta 1$ and BMP expression and signaling. A: Concentrations of BMP2, TGF- $\beta$, and activin proteins measured by enzyme-linked immunosorbent assay in lung lysates 14 days after intratracheal administration of bleomycin compared with in saline-inoculated controls. B: Representative Western blot showing $\mathrm{PO}_{4}$ Smad2, total Smad2, and GAPDH expression and densitometry analysis of the ratio of $\mathrm{PO}_{4} \mathrm{Smad} 2$ to total Smad2. C: Representative Western blot showing $\mathrm{PO}_{4} \mathrm{Smad} 1 / 5 / 8$, total Smad1/ $5 / 8$, and GAPDH expression and densitometry analysis of the ratio of $\mathrm{PO}_{4} \mathrm{Smad1/5/8}$ to total Smad1/5/ 8. Data expressed as medians \pm interquartile range (B and $\mathbf{C}) . n=8$ per group $(\mathbf{A}-\mathbf{C})$. ${ }^{*} P<0.05$, ${ }^{* *} P<0.01$, U-test. B, bleomycin-treated; BMP, bone morphogenetic protein; $C$, saline control; PS, pooled sample; TGF- $\beta$, transforming growth factor $\beta$.

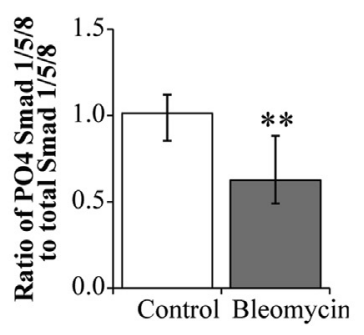

inflammatory cells, and significant alveolar injury with loss of airspace, thickening of alveolar walls, and intraalveolar inflammatory cells in the bleomycin-treated mice compared with in the normal saline controls, which was consistent with fibrotic injury. Stereological analysis confirmed that the bleomycin-treated mice had an increase in the total volume of lung tissue, reflecting inflammatory cell infiltration and fibrotic matrix deposition (Figure 1D). Picrosirius red staining showed increased collagen in sections from bleomycin-inoculated lungs when compared with saline controls (Figure 1C). The mean area of collagen identified by birefringence in picrosirius red-stained sections was significantly $(P<0.01)$ elevated in the bleomycin-injured lungs (3.84 $\pm 0.51 \%, n=8)$ when compared with salineinoculated lungs $(3.00 \pm 0.45 \%, n=7)$.

Collagen accumulation is a major feature of fibrosis, and one of the most important mediators of collagen synthesis is TGF- $\beta 1 .^{27,28}$ We therefore investigated the levels of expression of two TGF- $\beta 1$-regulated genes, Collal and Ctgf, which are characteristically elevated in the bleomycin-induced pulmonary fibrosis model. Collal and Ctgf were significantly increased in the bleomycintreated mice (Figure 1, E and F), which was in keeping with an established profibrotic state. Taken together with the histological findings, these results show a pattern typical of bleomycin-induced fibrosis.

\section{The mRNA Expression of BMP-Related Signaling Molecules Is Altered in Fibrotic Lungs}

To investigate the expression of BMP accessory proteins in fibrosis and TGF- $\beta 1 /$ BMP signaling, we examined the mRNA expression of a panel of extracellular BMPrelated signaling molecules (Table 3). With regard to RNA of the BMP accessory proteins known to interact with BMP alone, gremlin 1 and noggin mRNA was significantly up-regulated after bleomycin treatment compared with saline-inoculated controls, chordin mRNA expression was significantly decreased in bleomycintreated mice, and there was no significant difference in expression of Bmper and Mgp mRNA (Table 3). With regard to the RNA of the BMP accessory proteins that predominantly interact with BMP and TGF- $\beta 1 /$ actin, follistatin and Fstl1 mRNA were significantly upregulated in bleomycin-treated mice, whereas Bambi, KCP, and Nov mRNA were significantly down-regulated in bleomycin-treated mice. There was no change in FSTL3 mRNA in the bleomycin-treated mice compared with in the saline controls. 
A

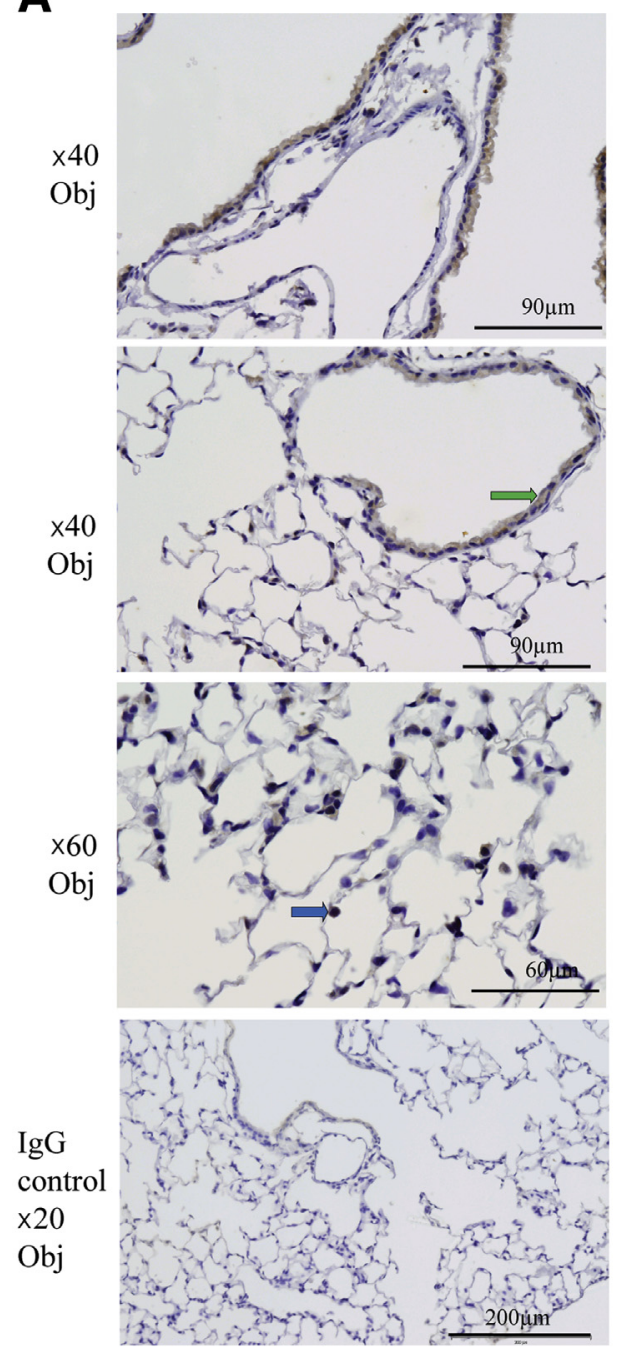

Bleomycin

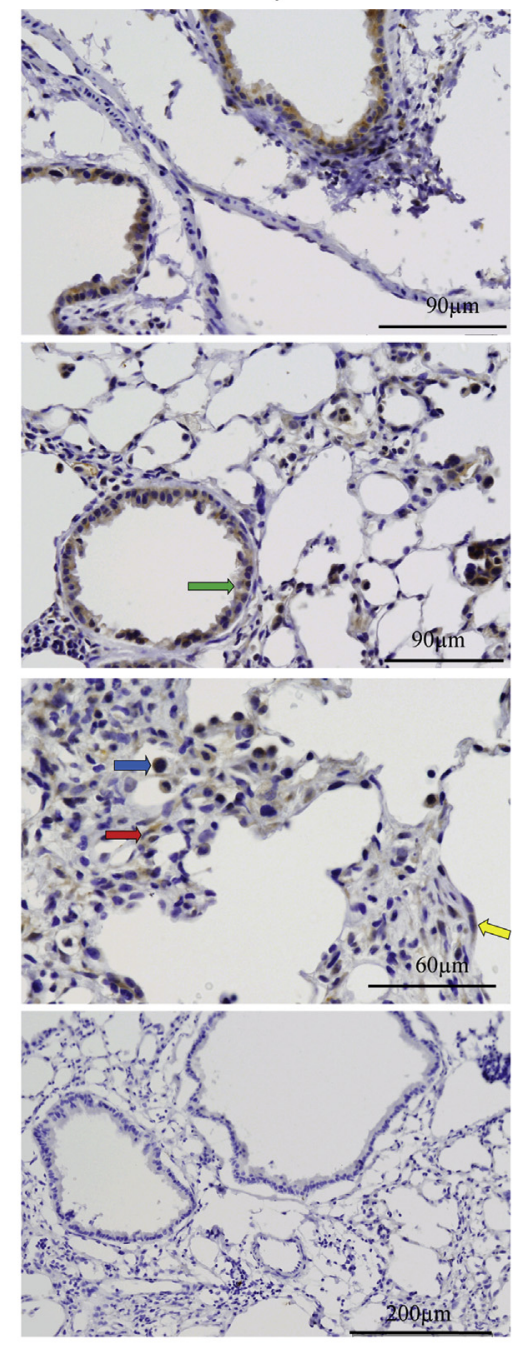

C

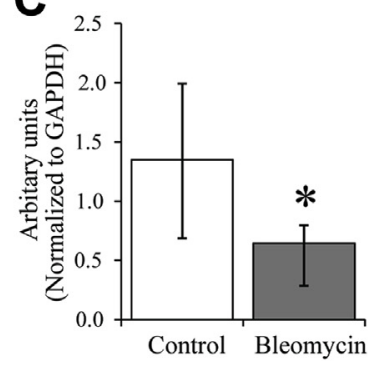

Figure 3 Investigation of noggin protein levels in intratracheal bleomycin-treated lungs. A: Localization of noggin by immunohistochemical staining. Upper six microscopic images ( $\times 40$ and $\times 60$ objectives) show noggin present in the epithelial cells of airways and alveolar macrophages in control and bleomycin-treated lungs and in the alveolar cells of bleomycin-treated animals. Bottom panels present concentration-matched nonimmune goat IgG showing absence of staining. Blue arrow indicates macrophage; green arrow, bronchial epithelium; yellow arrow, pneumocytes; and red arrow, fibroblasts. B: Representative Western blot showing expression of noggin protein in lungs 14 days after intratracheal administration of bleomycin compared with saline-inoculated controls. C: Densitometry analysis of noggin protein expression normalized to GAPDH. Data are expressed as medians \pm interquartile range (C). $n=8$ per group $(\mathbf{C}) .{ }^{*} P<0.05$, $U$-test. B, bleomycin-treated; C, saline control; Obj, objective; PS, pooled sample.

\section{B}

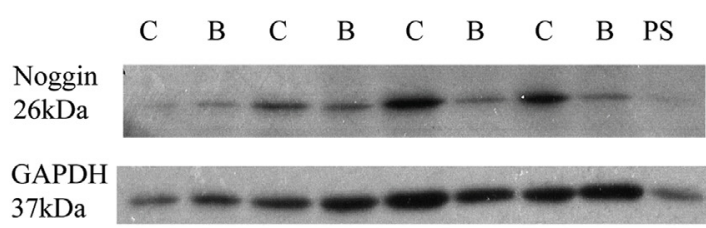

compared with in the controls (Figure 2A). Concomitant with this, we found increased levels of activin, which is also implicated in fibrotic disease, ${ }^{45}$ and reduced levels of BMP2 (Figure 2A). TGF- $\beta 1$ and BMP signal through a heteromeric cell surface serine/threonine kinase complex,${ }^{46}$ resulting in the receptor-mediated phosphorylation and activation of either Smad2/3 (TGF- $\beta 1$ and activin) or Smad1/5/8 (BMPs) transcription factors and alterations in gene transcription. Corresponding to increased levels of TGFB1 and activin, we found that the ratio of phospho-Smad2 to total Smad2 was significantly increased in the bleomycin-treated lungs (Figure 2B). 
Table 4 Comparison of Cellular Location of Noggin, BAMBI, and FSTL1 in Human Lung Specimens and Saline-Inoculated (Control) and Bleomycin-Inoculated Mouse Lungs

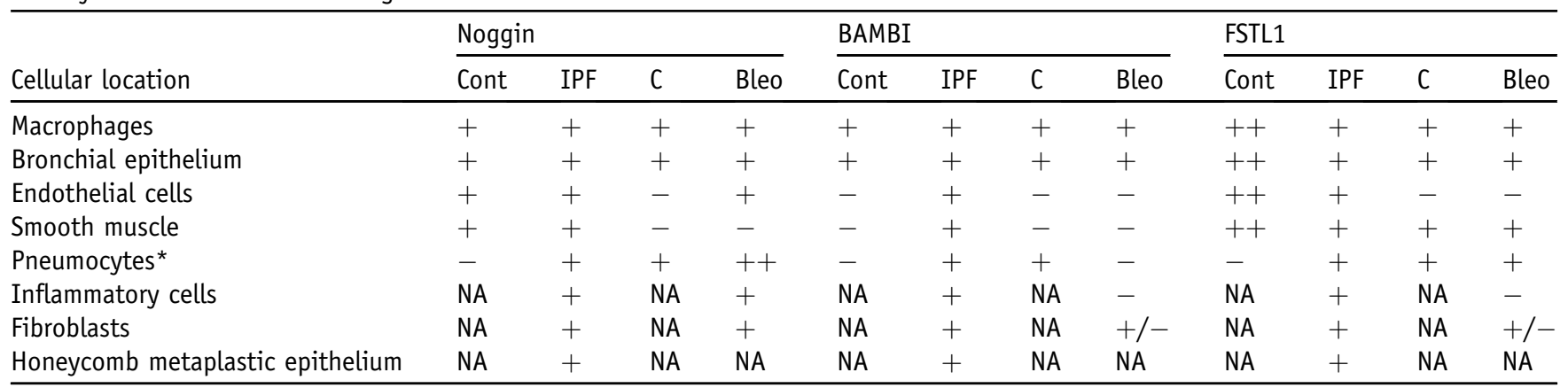

*Type 2 pneumocyte hyperplasia in IPF and bleomycin-injured lungs.

+ , present; -, absent; Bleo, bleomycin-inoculated mice; C, saline-inoculated control mice; Cont, control human lung tissue; IPF, lung tissue from IPF lungs; NA, not applicable.

However, there was no significant difference in the ratio of phospho-Smad3 to total Smad3 (data not shown). The ratio of phospho-Smad $1 / 5 / 8$ to total Smad $1 / 5 / 8$ was significantly reduced after bleomycin treatment (Figure 2C), which is consistent with reduced BMP signaling.

Noggin was detected in macrophages and bronchial epithelial cells of control and bleomycin-treated lungs, type II pneumocytes, inflammatory cells, and fibroblasts of bleomycin-treated lungs (Figure 3A, Table 4). In addition, noggin was detected in the vascular endothelium of the bleomycin-treated lungs (Supplemental Figure S1). There was no staining in specimens stained with nonimmune goat $\operatorname{IgG}$ instead of primary antibody (Figure 3A). Immunohistochemical analysis showed more intense staining of protein in bleomycin-treated lungs (Table 4). Western blot analysis detected a single band at the expected molecular weight of noggin (Figure 3B), which showed decreased levels of noggin in the bleomycin-treated lungs (Figure 3C).

BAMBI was localized in the macrophages and bronchial epithelium of control and bleomycin-treated lungs. Occasional fibroblasts positive for BAMBI were also seen in bleomycin-treated lungs (Figure 4A, Table 4). There was no staining in specimens when nonimmune goat $\operatorname{IgG}$ was substituted for primary antibody at the same concentration (Figure 4A). Western blot analysis visualized BAMBI as two bands, which is consistent with N-glycosylation (Figure 4B). The higher-molecular-weight band, which represents the glycosylated form of protein, was seen to be more highly expressed in bleomycin-treated mice (Figure 4C), whereas the lower molecular weight band was only detected in salineinoculated mice.

FSTL1 was localized in the macrophages, bronchial epithelium, and smooth muscle cells of control and bleomycin-treated lungs, but in type II pneumocytes and occasional fibroblasts of just the bleomycin-treated lungs (Figure 5A, Table 4). There was no staining in sections in which the same concentration of nonimmune goat $\operatorname{IgG}$ was used instead of primary antibody (Figure 5A). Immunohistochemical analysis showed more intense staining in bleomycin-treated lungs compared with in saline controls (Figure 5). FSTL1 is a 46-kDa protein that appeared as a doublet on immunoblot because of glycosylation (Figure 5B), which is consistent with previous reports. ${ }^{47}$ Densitometry demonstrated a significant increase of expression of FSTL1 protein (both bands) in the bleomycin-treated lungs (Figure 5C).

\section{Noggin, FSTL1, and BAMBI Are Expressed in Human Fibrotic Disease}

To see whether alterations of BMP accessory proteins occur in humans with fibrotic lung disease, we used sections from patients with IPF $(n=6)$ and control lung $(n=3)$. Noggin, BAMBI, and FSTL1 were all present in macrophages, type II pneumocytes, endothelial cells, and smooth muscle cells of both healthy lungs and those for individuals with IPF (Table 4 and Figure 6). In addition, these proteins were also present in areas of fibroblastic focus and honeycomb metaplastic epithelium, which is characteristic of fibrotic lung disease.

\section{TGFB1 Stimulation Increases the Expression of Noggin,} FSTL1, and BAMBI mRNA Expression in Human SAECs

TGFB1 is known to regulate many BMP accessory proteins. This means that there may be a feedforward loop whereby increased BMP antagonism results in increased TGFB1 signaling, which in turn increases levels of BMP accessory proteins further. We therefore tested whether TGFB1 induced changes in the expression of noggin, FSTL1, and BAMBI by using human SAECs. To confirm TGF- $\beta 1$-induced responses in the SAECs, we first measured mRNA expression levels of the TGF$\beta 1$-inducible genes COL1Al and CTGF, and demonstrated significant increases of both genes (twofold and threefold, respectively). Further measurement of the BMP accessory proteins noggin, FSTL1, and BAMBI (Figure 7), demonstrated that mRNA expression was 
A

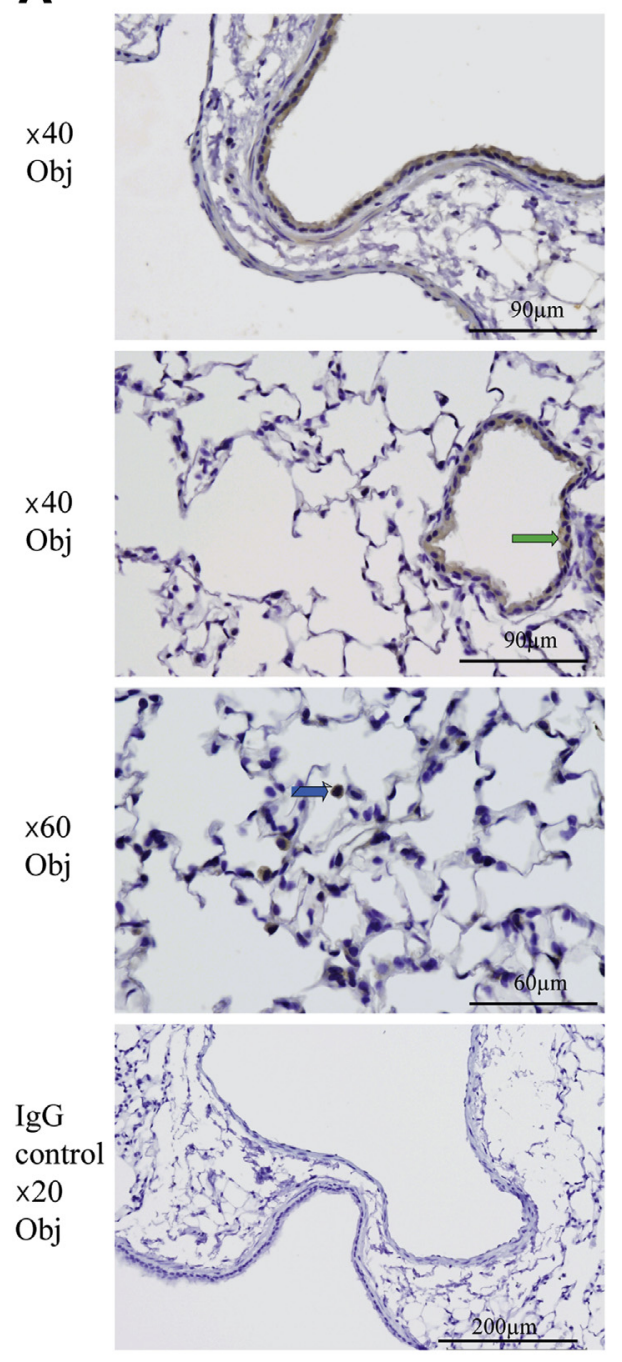

B

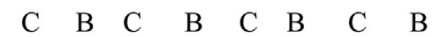

\section{Bleomycin}

\section{0}
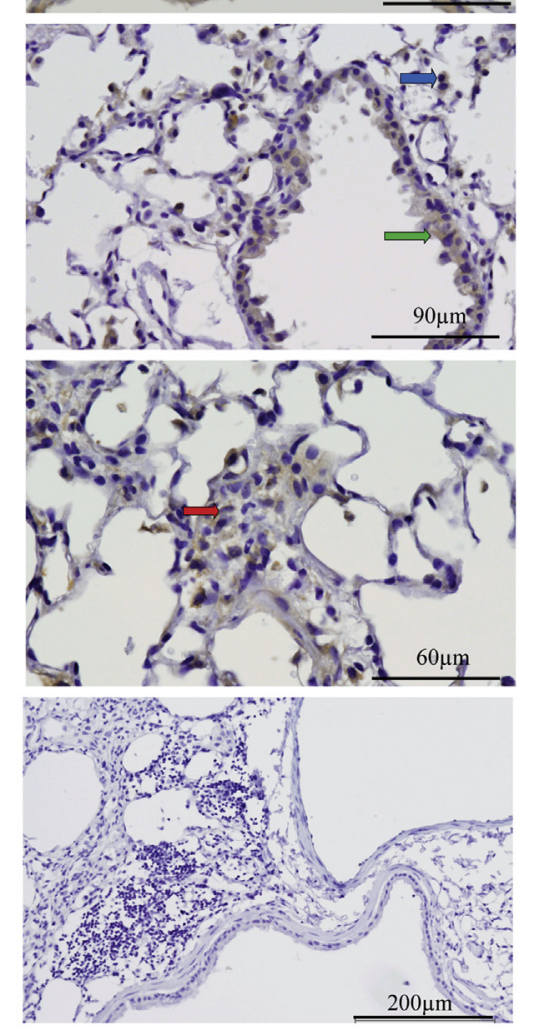

C

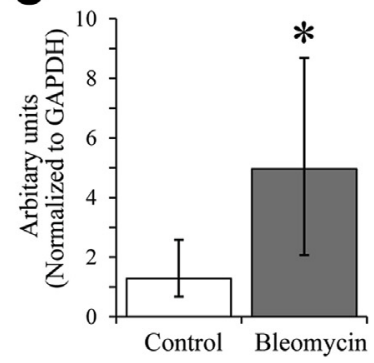

PS
Figure 4 Investigation of BAMBI protein levels in intratracheal bleomycin-treated lungs. A: Localization of BAMBI by immunohistochemical staining. Upper six microscopic images $(\times 40$ and $\times 60$ objectives) show BAMBI present in the epithelial cells of airways and alveolar macrophages in control and bleomycin-treated lungs and in the alveolar cells of bleomycin-treated animals. Bottom panels present concentrationmatched nonimmune goat IgG showing absence of staining. Blue arrow indicates macrophage; green arrow, bronchial epithelium; red arrow, fibroblasts. B: Representative Western blot showing expression of BAMBI protein in lungs 14 days after intratracheal administration of bleomycin compared with saline-inoculated controls. C: Densitometry analysis of BAMBI protein expression normalized to GAPDH. Data are expressed as medians \pm interquartile range (C). $n=8$ per group (C). ${ }^{*} P<0.05, U$-test. $\mathrm{B}$, bleomycin-treated; C, saline control; Obj, objective; PS, pooled sample.

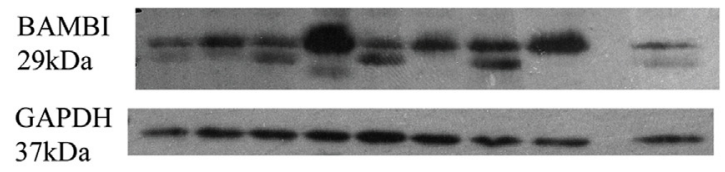


A

$\times 40$

$\mathrm{Obj}$

$\times 40$

Obj

$x 60$

Obj
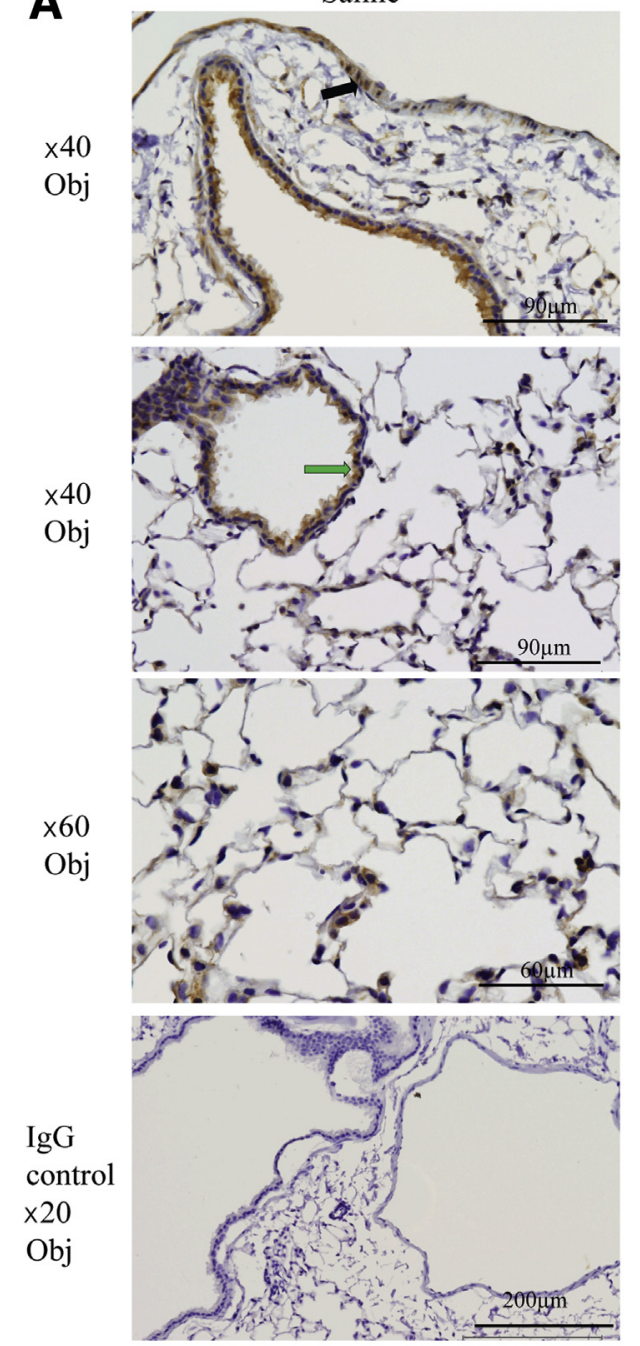

s.

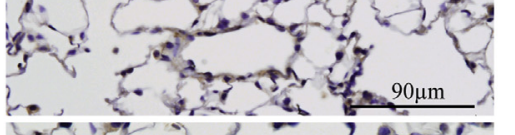

(1.

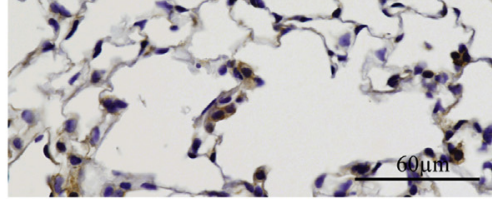

Saline
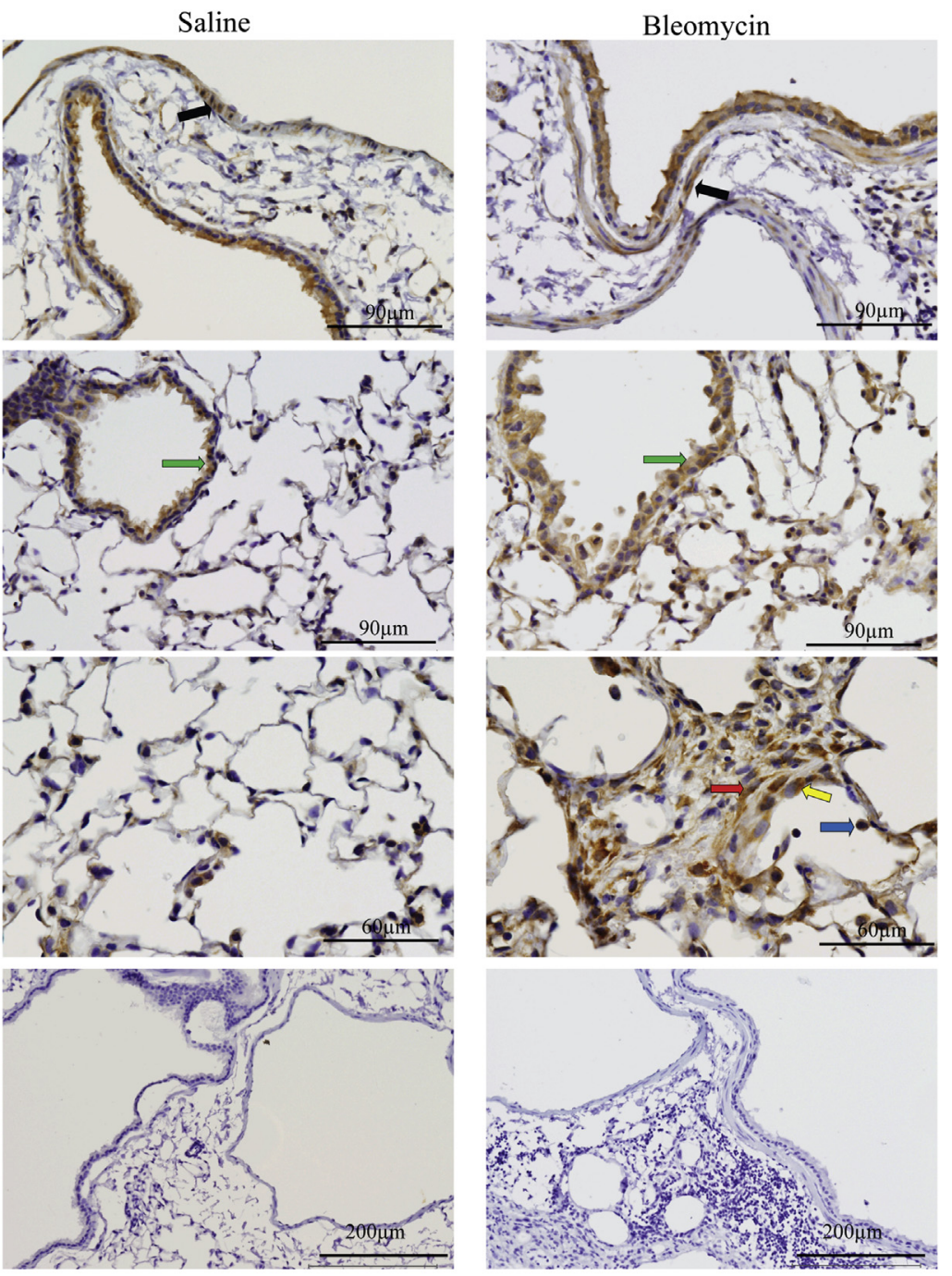

Figure 5 Investigation of levels of FSTL1 protein in intratracheal bleomycin-treated lungs. A: Localization of FSTL1 by immunohistochemical staining. Upper six microscopic images $(40 \times$ and $60 \times$ objectives) show FSTL1 present in the epithelial cells of airways and alveolar macrophages in control and bleomycin-treated lungs, and in the alveolar cells of bleomycin-treated animals. Bottom panels: Concentration-matched nonimmune goat IgG showing absence of staining. Blue arrow indicates macrophage; green arrow, bronchial epithelium; yellow arrow, pneumocytes; red arrow, fibroblasts; black arrow; smooth muscle cells. B: Representative Western blot showing expression of FSTL1 protein in lungs 14 days after intratracheal bleomycin compared to saline inoculate controls. C: Densitometry analysis of FSTL1 protein expression normalized to GAPDH. Data are expressed as medians \pm interquartile range $(\mathrm{C}) . n=8$ per group $(\mathrm{C}) .{ }^{*} P<0.05, U$-test. $\mathrm{B}$, bleomycin treated; C, saline control; $0 \mathrm{bj}$, objective; PS, pooled sample.

\section{B}

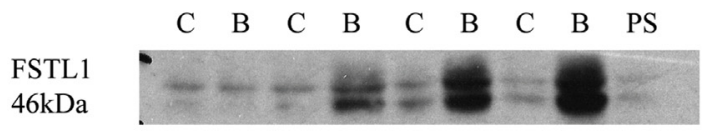

GAPDH

$37 \mathrm{kDa}$

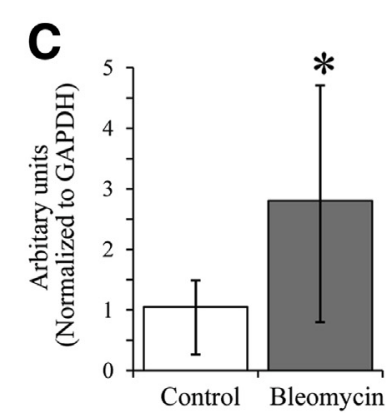

accessory proteins in lung fibrosis, ${ }^{1}$ this is the first study to examine the expression of multiple BMP accessory proteins during the fibrotic process.

\section{Bleomycin-Induced Pulmonary Fibrosis}

Bleomycin-treated mice were used as a model for fibrosis as they have previously been shown to model changes seen in human lung injury. ${ }^{10}$ The mice used in these experiments were confirmed to have an established profibrotic state as they had characteristics consistent with fibrosis: increased weight and volume of lungs (Figure $1, \mathrm{~A}$ and $\mathrm{B}$ ) ${ }^{50-52}$ bronchiocentric fibrotic change, thickening of alveolar walls, obliteration of airspace and inflammatory cell infiltrates (Figure 1C), ${ }^{53}$ increased volume of lung tissue because of inflammatory cell infiltrates, fibrotic matrix deposition (Figure 1D), and increased collagen as identified by picrosirius red-induced birefringence. In addition, the bleomycininoculated lungs showed increased levels of TGF- $\beta$, increased phosphorylation of SMAD2, and increased mRNA expression of the TGF- $\beta 1$-inducible profibrotic genes Collal and $\operatorname{Ctg} f$ (Figure 2), ${ }^{27,28}$ all of which are compatible with the 


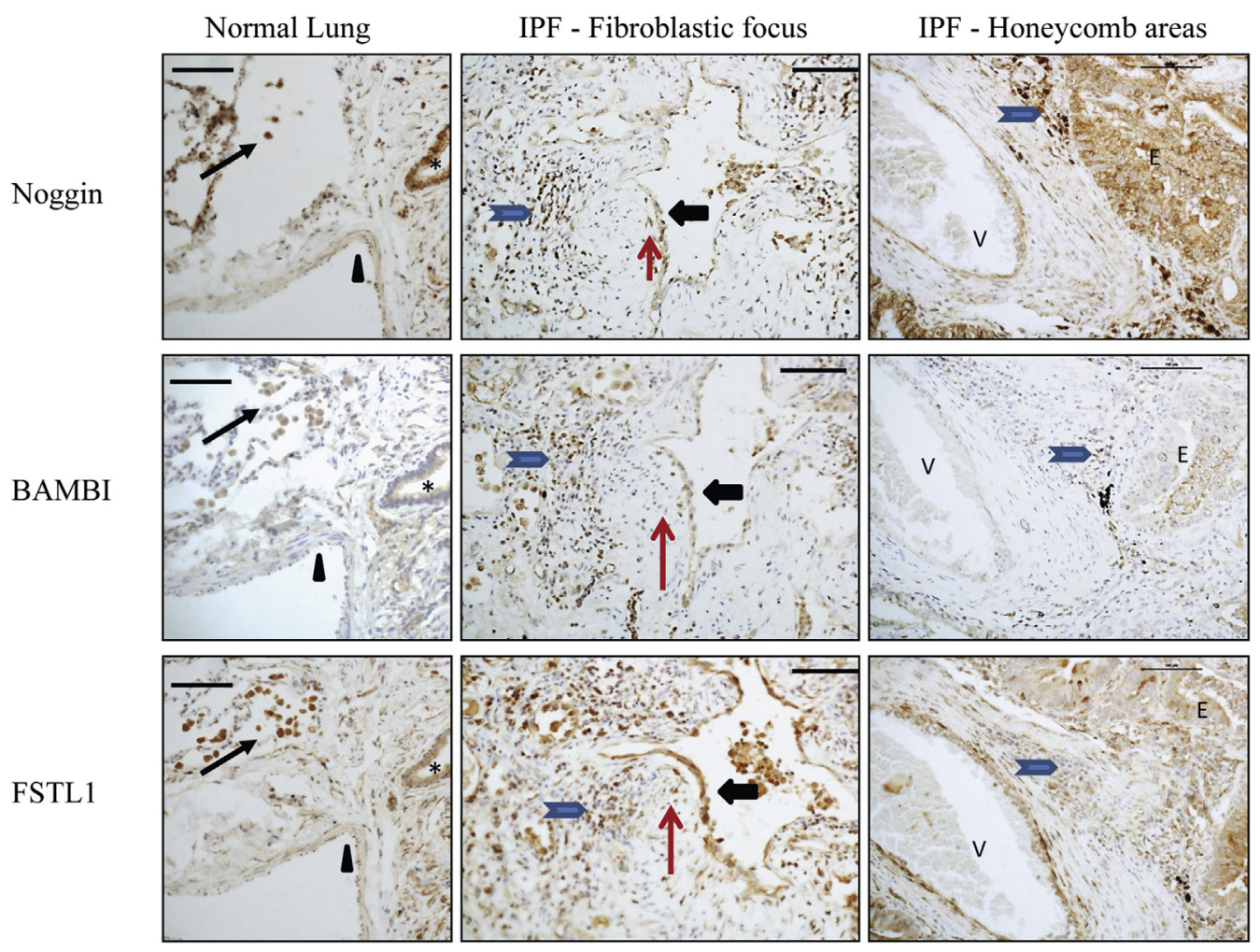

Figure 6 Immunohistochemical localization of bone morphogenetic protein accessory proteins in human lungs. Noggin, BAMBI, and FSTL1 are all present in macrophages and pneumocytes in the normal lung. In IPF lungs, all three proteins are present in macrophages, type II pneumocytes, inflammatory aggregates, and metaplastic epithelia. Black arrow indicates macrophage; long arrow, alveolar macrophages; star, bronchial epithelium; arrowhead, endothelial cells; red arrow, fibroblasts of the fibroblastic focus; short, thick black arrow, overlying type II pneumocyte hyperplasia; blue arrow, indicates inflammatory aggregate. All images were acquired on a $\times 20$ objective. Scale bar $=200 \mu \mathrm{m}$. E, metaplastic epithelium in honeycomb areas; IPF, idiopathic pulmonary fibrosis; $V$, vessel.

increased TGFB signaling typically observed during the development of lung fibrosis.

\section{Altered BMP Accessory Protein Expression in Fibrotic Lungs}

Initial investigation of BMP accessory proteins found alterations in the mRNA expression of multiple genes in the fibrotic lungs: Gremlin 1, Noggin, Follistatin, and Fstll were all significantly up-regulated; whereas Chordin, $K c p$, Nov, and $B a m b i$ were significantly down-regulated (Table 3). Although levels of mRNA expression can give some indication as to changes occurring during fibrosis, post-translational modifications are an important mechanism regulating expression of many proteins. We therefore looked in greater detail at the protein expression of three targets: noggin, BAMBI, and FSTL1. These BMP accessory proteins were chosen because this was the first time they had been examined in a model of fibrotic lung disease, although the expression of each had been implicated previously in fibrosis in other organs. ${ }^{54,55}$ Noggin is an example of a protein acting solely as a BMP-binding protein; it inhibits the actions of BMP2, 4 , and $7 .{ }^{35,56}$ In addition to binding BMP2 and 4, BAMBI and FSTL1 also affected TGF- $\beta 1 /$ activin binding ${ }^{9,39}$ and had opposing changes in mRNA expression, decreased and increased, respectively.

\section{Alterations in Expression of Noggin Protein}

In the bleomycin mouse model, noggin staining was more extensive in immunohistochemical analysis, which is consistent with increased mRNA expression (Figure 3A); however, Western blot analysis suggested that the expression was decreased in bleomycin-treated mice compared with in controls (Figure 3C). This difference between the immunohistochemical and Western blot analyses may be explained by a number of potential mechanisms. First, apparent changes in intensity on immunohistochemical analysis are often difficult to judge unless they are very large (presence or absence), so this technique primarily gives information about cellular location rather than concentration of a protein. Second, increased expression in specific subpopulations of cells within the lung might lead to increased intensity of staining in those cells. However, Western blot analysis provides an index of the concentration averaged throughout all cells within the lung. Thus, noggin is diluted by protein extracted from cells that do not express it and by extracellular soluble proteins. If other such soluble proteins were increased in the fibrotic lung, because of either proliferation or infiltration, the 

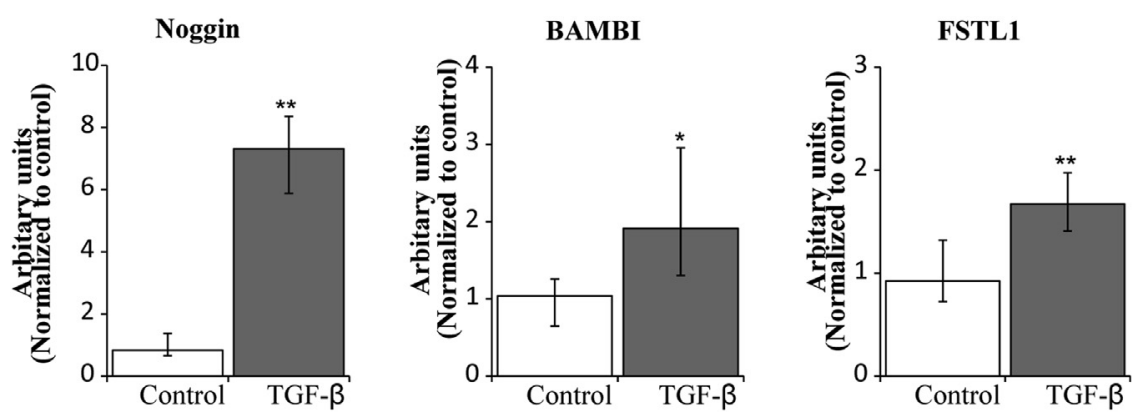

Figure 7 mRNA expression of noggin, BAMBI, and FSTL1 in SAECS stimulated with transforming growth factor $\beta$ (TGF- $\beta$ ) or vehicle. Data are expressed as medians \pm interquartile range. Values are normalized to $18 \mathrm{~s}$ rRNA and expressed as fold change relative to vehicle-treated controls. $n=12$ per group. ${ }^{*} P<0.05,{ }^{* *} P<0.01$ compared with vehicle-treated SAEC control (U-test). SAEC, small airway epithelial cell; TGF- $\beta$, transforming growth factor $\beta$.

effect would be to reduce noggin levels detected by Western blot analysis. A second possibility is selective loss of noggin during protein extraction for Western blot analysis. For example, this might occur because of very avid binding of noggin to the cellular glycocalyx on cell surfaces.

Noggin is glycosylated, and matrix binding is a property of such proteins. It has been shown previously that noggin binds to the glycocalyx and that this bound protein is not effectively extracted by standard tissue lysis techniques. Moreover, noggin bound to the glycocalyx remains an effective blocker of BMP signaling. ${ }^{57}$ Noggin bound to the cellular glycocalyx in such a manner would be stained in fixed sections and would appear in a cellular distribution.

Finally, nonspecific sticking of the noggin antibody to the tissue section must always be considered in these circumstances. However, nonimmune immunoglobulin of the same type that was prepared from the same species did not produce such nonspecific staining. Furthermore, we used the same antinoggin antibody in both Western blot and immunohistochemical analysis, and it identified a single band at the correct molecular weight. Further work will be required to determine the exact modulating role of noggin in BMP signaling in pulmonary fibrosis and thus in influencing the abnormal TGF$\beta 1$ - BMP balance observed in the fibrotic process.

Of note, our findings in human SAECs demonstrate that TGF- $\beta 1$ drives an increase in noggin that could inhibit BMP and potentiate the profibrotic action of TGF- $\beta 1$. This represents a feedforward mechanism that could drive fibrosis. Noggin acts as a BMP antagonist by binding directly to BMP molecules, preventing BMP from binding to the BMP receptor. ${ }^{56}$ This leads to a reduction in signaling through the Smad1/5/8 pathway and to a concomitant increase in $\operatorname{Smad} 2 / 3$ pathway. Any local increase in noggin protein in the bleomycin-treated lungs may therefore repress the BMP signaling pathway and boost the TGF- $\beta 1$ signaling pathway, thus increasing fibrosis. Moreover, the finding in SAECs that noggin mRNA expression was increased by stimulation with TGF- $\beta 1$ (Figure 7) suggests that fibrosis will be further enhanced, favoring maladaptive fibrotic healing rather than repair.

\section{Alterations in BAMBI Protein Expression}

In the bleomycin mouse model, BAMBI protein was more highly expressed, as demonstrated by both immunohistochemical and Western blot analysis (Figure 4), in contrast to the lower levels of mRNA expression. A similar opposing finding has been seen in liver cells, in which low levels of mRNA expression correlated with high protein levels in primary human hepatocytes. ${ }^{55}$ On the Western blot there were two bands: the heavier band was present in both the control and bleomycin-treated mice, although it was more highly expressed in the bleomycin-treated mice. The smaller band was present only in the control mice. It is possible that BAMBI protein becomes glycosylated and membrane bound during fibrotic lung injury, causing the protein to become more stable, with less degradation. So although mRNA expression decreases, and there is less protein production and the overall level of stable glycosylated protein is increased by post-translational modifications. This may be due to the effects of post-translational glycosylation, as the heavier, more glycosylated form of BAMBI had higher expression in the bleomycin-treated mice (Figure 4C), and likewise in the liver, primary human hepatocytes produced a glycosylated form of BAMBI.$^{55}$ BAMBI is a pseudoreceptor, with an extracellular domain similar to that of type I TGF- $\beta 1$ receptors but no intracellular kinase domain. It acts as a decoy receptor and has been reported to antagonize both the BMP and TGF- $\beta 1$ / activin signaling pathways by preventing the formation of active receptor complexes on binding. ${ }^{9}$ In cardiac and hepatic cells, BAMBI protects against fibrosis through blocking of TGF- $\beta$ signaling. ${ }^{55,58}$ This suggests that the increased levels of BAMBI protein found in both the bleomycin mouse model and IPF patients may be a protective measure to block excessive TGF- $\beta 1$ signaling and lessen pathological fibrosis.

\section{Alterations in FSTL1 Protein Expression}

In the bleomycin mouse model, FSTL1 protein was upregulated, as seen by immunohistochemical analysis and Western blot analysis consistent with the mRNA expression (Figure 4). During the course of preparation of this manuscript, another study that also reports increased Fstll expression in bleomycin-treated lungs was published. ${ }^{59}$ FSTL1 has been shown to act by directly binding to BMP, preventing binding to its receptor complex, and thereby blocking downstream SMAD signaling. ${ }^{38}$ In addition, FSTL1 has been shown to bind to TGF- $\beta 1 /$ activin complex. ${ }^{39}$ Our study reinforces the finding that FSTL1 likely plays an important role in lung 
fibrosis, with increases in the protein helping to promote the fibrotic phenotype.

In the human lung tissue, noggin, BAMBI, and FSTL1 were all detected in fibrotic areas (Figure 6). There is considerable concordance in the cellular distribution of these BMP antagonists in human and mouse lungs. Macrophages and bronchial epithelium express all three glycoproteins in both species, as do the alveolar pneumocytes (Table 4). Furthermore, in both humans and mice, fibroblasts express these three BMP antagonists in fibrotic conditions. In contrast, within the pulmonary vascular cells, only noggin is expressed in both human and mouse endothelium, and in smooth muscle cells only FSTL1 is expressed in both (Table 4). As is well known, the bleomycin model does not reproduce the human disease, and thus no honeycombing or fully developed fibroblastic foci are seen in the mouse lungs. Nonetheless, the extensive concordance observed suggests that the bleomycin model will provide a useful tool to further explore the role of these glycoproteins in fibrotic lung diseases.

\section{TGF- $\beta 1$-Induced Changes in Expression of BMP Accessory Proteins}

All three of these proteins are glycoproteins, so it is likely that upon glycosylation they will stick to the cellular glycocalyx close to the site of production and act in a local context with specific functions. Thus, the exact role of these secreted proteins needs to be explored separately in cellspecific contexts. Because all three proteins were highly expressed in epithelial cells, we used SAECs to look for regulatory feedback loops that may occur in this cell type and gain greater insight into whether it is only the initial injury that causes increased expression of these proteins or whether TGF- $\beta 1$ also plays a role. In this study, we found that TGF- $\beta 1$ stimulation increased the expression of noggin, BAMBI, and FSTL1, suggesting that after injury, TGF- $\beta 1$ release can further drive the fibrotic phenotype in this cellspecific context.

\section{Potential Influence of Sex in Pulmonary Fibrosis}

It is important to note that we used male mice in all experiments and that the explanted lung tissue came from male patients. There are sex-based differences in the severity of pulmonary fibrosis in the bleomycin mouse model, with more severe lung disease developing in male mice. ${ }^{60}$ Therefore, when designing our experiments, we used only male mice so that any differences seen would be due to the effects of bleomycin and not confounded by a sex-based effect. Furthermore, IPF is much more common in males than in females, which is why all our human lung samples are from male lungs. In view of this, further work will be required to determine whether the same changes in BMP antagonists are observed in lung fibrosis in females; caution must be exercised before extrapolating these results directly.

\section{Conclusions}

The work presented in this study reveals for the first time that there is altered expression of a number of BMP accessory proteins in the murine model of lung injury. We also provide evidence that, for some of these proteins, posttranslational mechanisms also play an important role in regulating expression. Clearly this may also be the case for other proteins in the family that we have not examined. Our results demonstrate that to fully understand the mechanisms underlying the altered TGF- $\beta 1-$ BMP balance, which plays such an important role in pulmonary fibrosis, the changes in the BMP/TGF- $\beta$ accessory proteins will need to be fully elucidated. Disturbances in these accessory proteins are likely to play an important role in the pathogenesis of IPF.

\section{Acknowledgments}

We thank Janet McCormack and Dimitri Scholz (Conway Institute, University College Dublin, Ireland) for technical assistance.

\section{Supplemental Data}

Supplemental material for this article can be found at http://dx.doi.org/10.1016/j.ajpath.2015.10.032.

\section{References}

1. Myllarniemi M, Lindholm P, Ryynanen MJ, Kliment CR, Salmenkivi K, Keski-Oja J, Kinnula VL, Oury TD, Koli K: Gremlinmediated decrease in bone morphogenetic protein signaling promotes pulmonary fibrosis. Am J Respir Crit Care Med 2008, 177:321-329

2. Budd DC, Holmes AM: Targeting TGFbeta superfamily ligand accessory proteins as novel therapeutics for chronic lung disorders. Pharmacol Ther 2012, 135:279-291

3. Koli K, Myllarniemi M, Vuorinen K, Salmenkivi K, Ryynanen MJ, Kinnula VL, Keski-Oja J: Bone morphogenetic protein-4 inhibitor gremlin is overexpressed in idiopathic pulmonary fibrosis. Am J Pathol 2006, 169:61-71

4. Cahill E, Costello CM, Rowan SC, Harkin S, Howell K, Leonard MO, Southwood M, Cummins EP, Fitzpatrick SF, Taylor CT, Morrell NW, Martin F, McLoughlin P: Gremlin plays a key role in the pathogenesis of pulmonary hypertension. Circulation 2012, 125:920-930

5. Bramlage CP, Haupl T, Kaps C, Ungethum U, Krenn V, Pruss A, Muller GA, Strutz F, Burmester GR: Decrease in expression of bone morphogenetic proteins 4 and 5 in synovial tissue of patients with osteoarthritis and rheumatoid arthritis. Arthritis Res Ther 2006, 8:R58

6. Eddy AA: Ramping up endogenous defences against chronic kidney disease. Nephrol Dial Transplant 2006, 21:1174-1177

7. Chen BL, Peng J, Li QF, Yang M, Wang Y, Chen W: Exogenous bone morphogenetic protein-7 reduces hepatic fibrosis in Schistosoma japonicum-infected mice via transforming growth factor-beta/Smad signaling. World J Gastroenterol 2013, 19:1405-1415

8. Balemans W, Van Hul W: Extracellular regulation of BMP signaling in vertebrates: a cocktail of modulators. Dev Biol 2002, 250:231-250

9. Onichtchouk D, Chen YG, Dosch R, Gawantka V, Delius H, Massague J, Niehrs C: Silencing of TGF-beta signalling by the pseudoreceptor BAMBI. Nature 1999, 401:480-485 
10. Izbicki G, Segel MJ, Christensen TG, Conner MW, Breuer R: Time course of bleomycin-induced lung fibrosis. Int J Exp Pathol 2002, 83: $111-119$

11. Nicklas W, Baneux P, Boot R, Decelle T, Deeny AA, Fumanelli M, Illgen-Wilcke B: FELASA: recommendations for the health monitoring of rodent and rabbit colonies in breeding and experimental units. Lab Anim 2002, 36:20-42

12. Degryse AL, Tanjore H, Xu XC, Polosukhin VV, Jones BR, McMahon FB, Gleaves LA, Blackwell TS, Lawson WE: Repetitive intratracheal bleomycin models several features of idiopathic pulmonary fibrosis. Am J Physiol Lung Cell Mol Physiol 2010, 299:L442-L452

13. Scherle W: A simple method for volumetry of organs in quantitative stereology. Mikroskopie 1970, 26:57-60

14. Hsia CC, Hyde DM, Ochs M, Weibel ER, Weibel ER, Albertine KH, Burri PH, Crapo JD, Fehrenbach H, Grenier PA, Gundersen HJ, Hoffman EA, Hogg JC, Jeffery PK, Mcloughlin P, Mayhew TM, Mitzner W, Plopper CG, Schuster DP, Woodruff P: An official research policy statement of the American Thoracic Society/European Respiratory Society: standards for quantitative assessment of lung structure. Am J Respir Crit Care Med 2010, 181:394-418

15. Schmittgen TD, Livak KJ: Analyzing real-time PCR data by the comparative C(T) method. Nat Protoc 2008, 3:1101-1108

16. Aoki F, Kurabayashi M, Hasegawa Y, Kojima I: Attenuation of bleomycin-induced pulmonary fibrosis by follistatin. Am J Respir Crit Care Med 2005, 172:713-720

17. Helbing T, Herold EM, Hornstein A, Wintrich S, Heinke J, Grundmann S, Patterson C, Bode C, Moser M: Inhibition of BMP activity protects epithelial barrier function in lung injury. J Pathol 2013, 231:105-116

18. Dromann D, Rupp J, Rohmann K, Osbahr S, Ulmer AJ, Marwitz S, Roschmann K, Abdullah M, Schultz H, Vollmer E, Zabel P, Dalhoff K, Goldmann T: The TGF-beta-pseudoreceptor BAMBI is strongly expressed in COPD lungs and regulated by nontypeable Haemophilus influenzae. Respir Res 2010, 11:67

19. Sylva M, Li VS, Buffing AA, van Es JH, van den Born M, van der Velden S, Gunst Q, Koolstra JH, Moorman AF, Clevers H, van den Hoff MJ: The BMP antagonist follistatin-like 1 is required for skeletal and lung organogenesis. PLoS One 2011, 6:e22616

20. Gilbert KA, Rannels SR: Matrix GLA protein modulates branching morphogenesis in fetal rat lung. Am J Physiol Lung Cell Mol Physiol 2004, 286:L1179-L1187

21. Scott IC, Steiglitz BM, Clark TG, Pappano WN, Greenspan DS: Spatiotemporal expression patterns of mammalian chordin during postgastrulation embryogenesis and in postnatal brain. Dev Dyn 2000, 217:449-456

22. Tsuchida K, Arai KY, Kuramoto Y, Yamakawa N, Hasegawa Y, Sugino H: Identification and characterization of a novel follistatin-like protein as a binding protein for the TGF-beta family. J Biol Chem 2000, 275:40788-40796

23. Liu C, Liu XJ, Crowe PD, Kelner GS, Fan J, Barry G, Manu F, Ling N, De Souza EB, Maki RA: Nephroblastoma overexpressed gene (NOV) codes for a growth factor that induces protein tyrosine phosphorylation. Gene 1999, 238:471-478

24. Cadogan E, Hopkins N, Giles S, Bannigan JG, Moynihan J, McLoughlin P: Enhanced expression of inducible nitric oxide synthase without vasodilator effect in chronically infected lungs. Am J Physiol 1999, 277:L616-L627

25. Raghu G, Collard HR, Egan JJ, Martinez FJ, Behr J, Brown KK, et al: An official ATS/ERS/JRS/ALAT statement: idiopathic pulmonary fibrosis: evidence-based guidelines for diagnosis and management. Am J Respir Crit Care Med 2011, 183:788-824

26. Walsh SM, Boylan DA, Worrell JC, Lumsden RV, Kane R, Keane MP: The myofibroblast in pulmonary fibrosis displays distinct functional characteristics, depending on its source of origin. Eur Respir J 2014, 44(Suppl. 58):P792

27. Roberts AB, Sporn MB, Assoian RK, Smith JM, Roche NS, Wakefield LM, Heine UI, Liotta LA, Falanga V, Kehrl JH, Fauci AS:
Transforming growth factor type beta: rapid induction of fibrosis and angiogenesis in vivo and stimulation of collagen formation in vitro. Proc Natl Acad Sci U S A 1986, 83:4167-4171

28. Wang Q, Wang Y, Hyde DM, Gotwals PJ, Koteliansky VE, Ryan ST, Giri SN: Reduction of bleomycin induced lung fibrosis by transforming growth factor beta soluble receptor in hamsters. Thorax 1999, 54:805-812

29. Moser M, Binder O, Wu Y, Aitsebaomo J, Ren R, Bode C, Bautch VL, Conlon FL, Patterson C: BMPER, a novel endothelial cell precursor-derived protein, antagonizes bone morphogenetic protein signaling and endothelial cell differentiation. Mol Cell Biol 2003, 23:5664-5679

30. Heinke J, Wehofsits L, Zhou Q, Zoeller C, Baar KM, Helbing T, Laib A, Augustin H, Bode C, Patterson C, Moser M: BMPER is an endothelial cell regulator and controls bone morphogenetic protein-4dependent angiogenesis. Circ Res 2008, 103:804-812

31. Piccolo S, Sasai Y, Lu B, De Robertis EM: Dorsoventral patterning in Xenopus: inhibition of ventral signals by direct binding of chordin to BMP-4. Cell 1996, 86:589-598

32. Hsu DR, Economides AN, Wang X, Eimon PM, Harland RM: The Xenopus dorsalizing factor Gremlin identifies a novel family of secreted proteins that antagonize BMP activities. Mol Cell 1998, 1: 673-683

33. Zebboudj AF, Imura M, Bostrom K: Matrix GLA protein, a regulatory protein for bone morphogenetic protein-2. J Biol Chem 2002, 277:4388-4394

34. Yao Y, Zebboudj AF, Shao E, Perez M, Bostrom K: Regulation of bone morphogenetic protein- 4 by matrix GLA protein in vascular endothelial cells involves activin-like kinase receptor 1. J Biol Chem 2006, 281:33921-33930

35. Zimmerman LB, De Jesus-Escobar JM, Harland RM: The Spemann organizer signal noggin binds and inactivates bone morphogenetic protein 4. Cell 1996, 86:599-606

36. Schneyer A, Schoen A, Quigg A, Sidis Y: Differential binding and neutralization of activins A and B by follistatin and follistatin like-3 (FSTL-3/FSRP/FLRG). Endocrinology 2003, 144:1671-1674

37. Nogai H, Rosowski M, Grun J, Rietz A, Debus N, Schmidt G, Lauster C, Janitz M, Vortkamp A, Lauster R: Follistatin antagonizes transforming growth factor-beta3-induced epithelial-mesenchymal transition in vitro: implications for murine palatal development supported by microarray analysis. Differentiation 2008, 76:404-416

38. Geng Y, Dong Y, Yu M, Zhang L, Yan X, Sun J, Qiao L, Geng H, Nakajima M, Furuichi T, Ikegawa S, Gao X, Chen YG, Jiang D, Ning W: Follistatin-like 1 (Fstl1) is a bone morphogenetic protein (BMP) 4 signaling antagonist in controlling mouse lung development. Proc Natl Acad Sci U S A 2011, 108:7058-7063

39. Tanaka M, Murakami K, Ozaki S, Imura Y, Tong XP, Watanabe T, Sawaki T, Kawanami T, Kawabata D, Fujii T, Usui T, Masaki Y, Fukushima T, Jin ZX, Umehara H, Mimori T: DIP2 discointeracting protein 2 homolog A (Drosophila) is a candidate receptor for follistatin-related protein/follistatin-like 1-analysis of their binding with TGF-beta superfamily proteins. FEBS J 2010, 277:4278-4289

40. Tortoriello DV, Sidis Y, Holtzman DA, Holmes WE, Schneyer AL: Human follistatin-related protein: a structural homologue of follistatin with nuclear localization. Endocrinology 2001, 142:3426-3434

41. Matsui M, Mizuseki K, Nakatani J, Nakanishi S, Sasai Y: Xenopus kielin: a dorsalizing factor containing multiple chordin-type repeats secreted from the embryonic midline. Proc Natl Acad Sci U S A 2000, 97:5291-5296

42. Lin J, Patel SR, Cheng X, Cho EA, Levitan I, Ullenbruch M, Phan SH, Park JM, Dressler GR: Kielin/chordin-like protein, a novel enhancer of BMP signaling, attenuates renal fibrotic disease. Nat Med 2005, 11:387-393

43. Lin J, Patel SR, Wang M, Dressler GR: The cysteine-rich domain protein $\mathrm{KCP}$ is a suppressor of transforming growth factor beta/activin signaling in renal epithelia. Mol Cell Biol 2006, 26:4577-4585 
44. Rydziel S, Stadmeyer L, Zanotti S, Durant D, Smerdel-Ramoya A, Canalis E: Nephroblastoma overexpressed (Nov) inhibits osteoblastogenesis and causes osteopenia. J Biol Chem 2007, 282: 19762-19772

45. Apostolou E, Stavropoulos A, Sountoulidis A, Xirakia C, Giaglis S, Protopapadakis E, Ritis K, Mentzelopoulos S, Pasternack A, Foster M, Ritvos O, Tzelepis GE, Andreakos E, Sideras P: Activin-A overexpression in the murine lung causes pathology that simulates acute respiratory distress syndrome. Am J Respir Crit Care Med 2012, 185:382-391

46. Feng XH, Derynck R: Specificity and versatility in tgf-beta signaling through Smads. Annu Rev Cell Dev Biol 2005, 21:659-693

47. Oshima Y, Ouchi N, Sato K, Izumiya Y, Pimentel DR, Walsh K: Follistatin-like 1 is an Akt-regulated cardioprotective factor that is secreted by the heart. Circulation 2008, 117:3099-3108

48. Yang G, Zhu Z, Wang Y, Gao A, Niu P, Tian L: Bone morphogenetic protein-7 inhibits silica-induced pulmonary fibrosis in rats. Toxicol Lett 2013, 220:103-108

49. Guo X, Wang XF: Signaling cross-talk between TGF-beta/BMP and other pathways. Cell Res 2009, 19:71-88

50. Serrano-Mollar A, Nacher M, Gay-Jordi G, Closa D, Xaubet A, Bulbena O: Intratracheal transplantation of alveolar type II cells reverses bleomycin-induced lung fibrosis. Am J Respir Crit Care Med 2007, 176:1261-1268

51. El-Khouly D, El-Bakly WM, Awad AS, El-Mesallamy HO, ElDemerdash E: Thymoquinone blocks lung injury and fibrosis by attenuating bleomycin-induced oxidative stress and activation of nuclear factor Kappa-B in rats. Toxicology 2012, 302:106-113

52. Hoyt DG, Lazo JS: Alterations in pulmonary mRNA encoding procollagens, fibronectin and transforming growth factor-beta precede bleomycin-induced pulmonary fibrosis in mice. J Pharmacol Exp Ther 1988, 246:765-771

53. Moeller A, Ask K, Warburton D, Gauldie J, Kolb M: The bleomycin animal model: a useful tool to investigate treatment options for idiopathic pulmonary fibrosis? Int J Biochem Cell Biol 2008, 40: 362-382

54. Shimano M, Ouchi N, Nakamura K, van Wijk B, Ohashi K, Asaumi Y, Higuchi A, Pimentel DR, Sam F, Murohara T, van den Hoff MJ, Walsh K: Cardiac myocyte follistatin-like 1 functions to attenuate hypertrophy following pressure overload. Proc Natl Acad Sci U S A 2011, 108:E899-E906

55. Wanninger J, Neumeier M, Bauer S, Weiss TS, Eisinger K, Walter R, Dorn C, Hellerbrand C, Schaffler A, Buechler C: Adiponectin induces the transforming growth factor decoy receptor BAMBI in human hepatocytes. FEBS Lett 2011, 585:1338-1344

56. Groppe J, Greenwald J, Wiater E, Rodriguez-Leon J, Economides AN, Kwiatkowski W, Affolter M, Vale WW, Izpisua Belmonte JC, Choe S: Structural basis of BMP signalling inhibition by the cystine knot protein Noggin. Nature 2002, 420:636-642

57. Paine-Saunders S, Viviano BL, Economides AN, Saunders S: Heparan sulfate proteoglycans retain Noggin at the cell surface: a potential mechanism for shaping bone morphogenetic protein gradients. J Biol Chem 2002, 277:2089-2096

58. Villar AV, Garcia R, Llano M, Cobo M, Merino D, Lantero A, Tramullas M, Hurle JM, Hurle MA, Nistal JF: BAMBI (BMP and activin membrane-bound inhibitor) protects the murine heart from pressure-overload biomechanical stress by restraining TGF-beta signaling. Biochim Biophys Acta 2013, 1832:323-335

59. Dong Y, Geng Y, Li L, Li X, Yan X, Fang Y, Li X, Dong S, Liu X, Li X, Yang $X$, Zheng $X$, Xie T, Liang J, Dai H, Liu X, Yin Z, Noble PW, Jiang D, Ning W: Blocking follistatin-like 1 attenuates bleomycin-induced pulmonary fibrosis in mice. J Exp Med 2015, 212:235-252

60. Redente EF, Jacobsen KM, Solomon JJ, Lara AR, Faubel S, Keith RC, Henson PM, Downey GP, Riches DW: Age and sex dimorphisms contribute to the severity of bleomycin-induced lung injury and fibrosis. Am J Physiol Lung Cell Mol Physiol 2011, 301: L510-L518 